\title{
The fortified settlement of Macapainara, Lautem District, Timor-Leste
}

\author{
Sue 0'Connor, David Bulbeck, Noel Amano Jr, Philip J. Piper, \\ Sally Brockwell, Andrew McWilliam, Jack N. Fenner, Jack 0'Connor- \\ Veth, Rose Whitau, Tim Maloney, Michelle C. Langley, Mirani Litster, \\ James Lankton, Bernard Gratuze, William R. Dickinson, \\ Anthony Barham and Richard C. Willan
}

\section{Introduction}

The hilltop location known as Macapainara is an extensive fortified settlement complex near the modern coastal village of Com (Figure 2.1). Although the settlement is no longer occupied, families living in the modern harbour village of Com identify it as their ancestral homeland and visit the ancestral graves in the settlement to perform rituals. Macapainara is $175 \mathrm{~m}$ above sea level and approximately $2 \mathrm{~km}$ in from the northern coastline of Timor-Leste (Figure 2.1). In 2008, excavations were carried out within the walls in order to assess the nature and chronology of occupation. The phenomenon of fort building and its chronology in Timor-Leste have been examined elsewhere (Fenner and Bulbeck 2013; O’Connor et al. 2012). Here we focus on describing the excavated cultural assemblage.

The Macapainara settlement occurs over two levels. The upper level, known as Ili Vali, references the large rocky bluff on which this part of the complex is located. Ili Vali has a narrow stone entrance way, several graves made of dressed stone and several large flat circular dressed disks made of a fine-grained sedimentary rock, identified locally by the term 'batu Makassar' (see McWilliam et al. 2012; Figure 2.2). The lower level, known as Macapainara, is surrounded by massive encircling stone walls to the north and south that are up to $3 \mathrm{~m}$ high and $2 \mathrm{~m}$ thick at the base. This area is a natural sediment trap and was selected for excavation as the part of the complex most likely to have a deep deposit. Macapainara has several graves, including one very large structure facing east-west identified as a double grave, containing the remains of the former ruler of Ili Vali/Macapainara and his close political ally (Figure 2.3) (McWilliam et al. 2012). This grave measures $3 \mathrm{~m}$ in length and c. $2.2 \mathrm{~m}$ in width. The base of the grave is constructed from shaped limestone blocks while the upper section is made from the flat slabs of dressed fine-grained sedimentary rock. At the time of our field visit a Chinese Blue and White tradeware bowl was placed on the surface (Figure 2.4). 


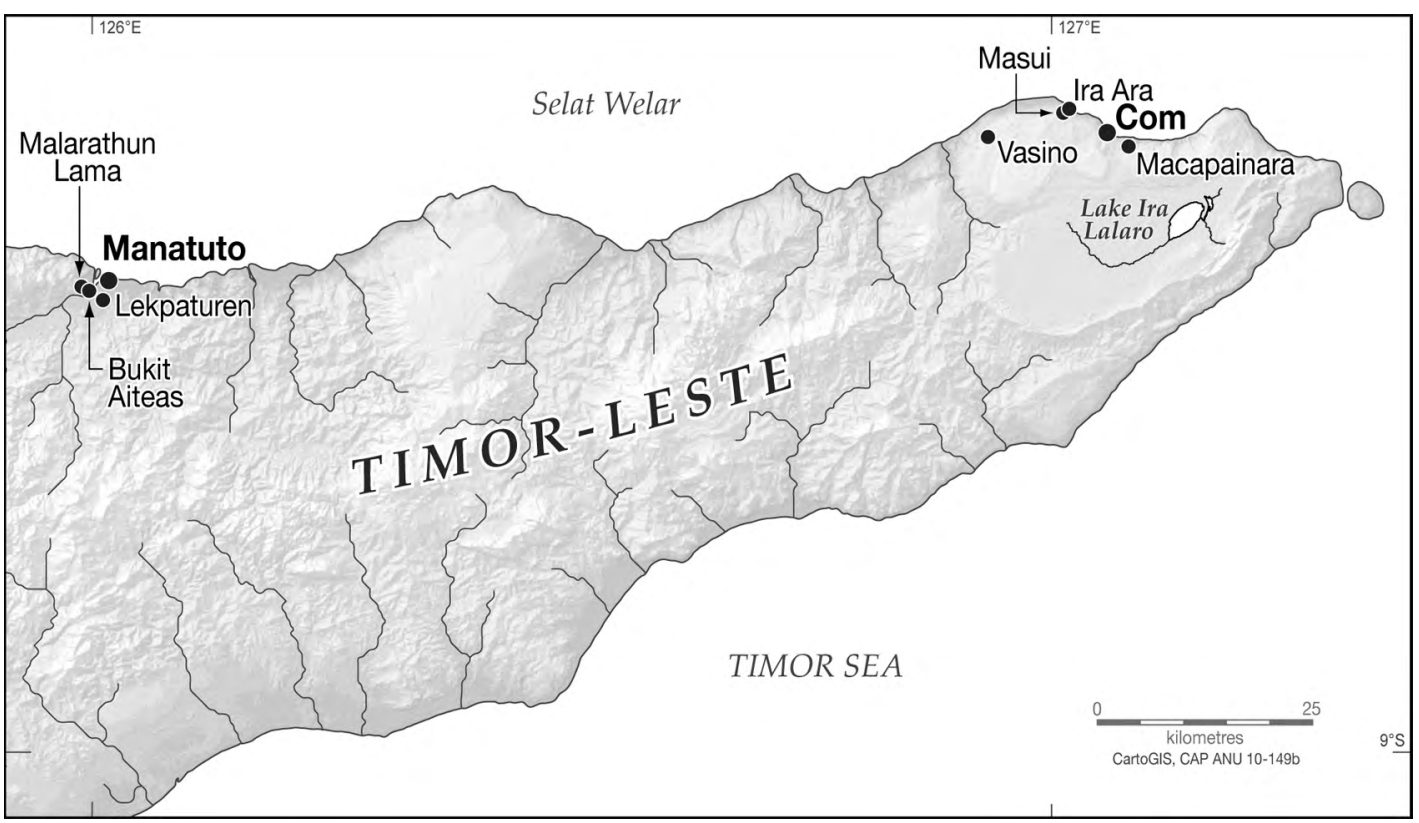

Figure 2.1. Location of Macapainara.

Source: CartoGIS ANU.

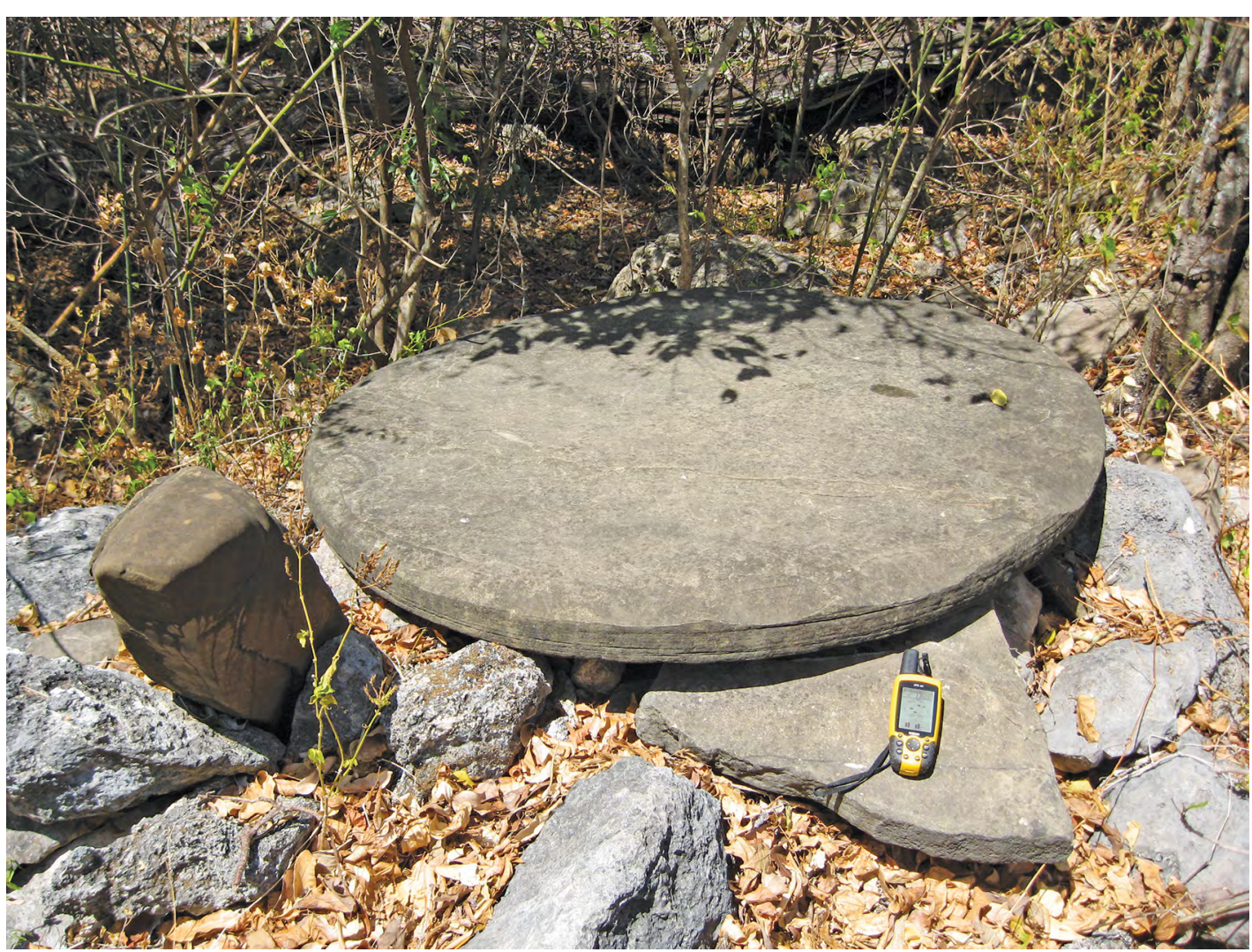

Figure 2.2. 'Batu Makassar' flat circular stone at Ili Vali with upright stone next to it. Both are shaped from a fine-grained sedimentary rock.

Source: Photo courtesy of Sue $0^{\prime}$ Connor. 


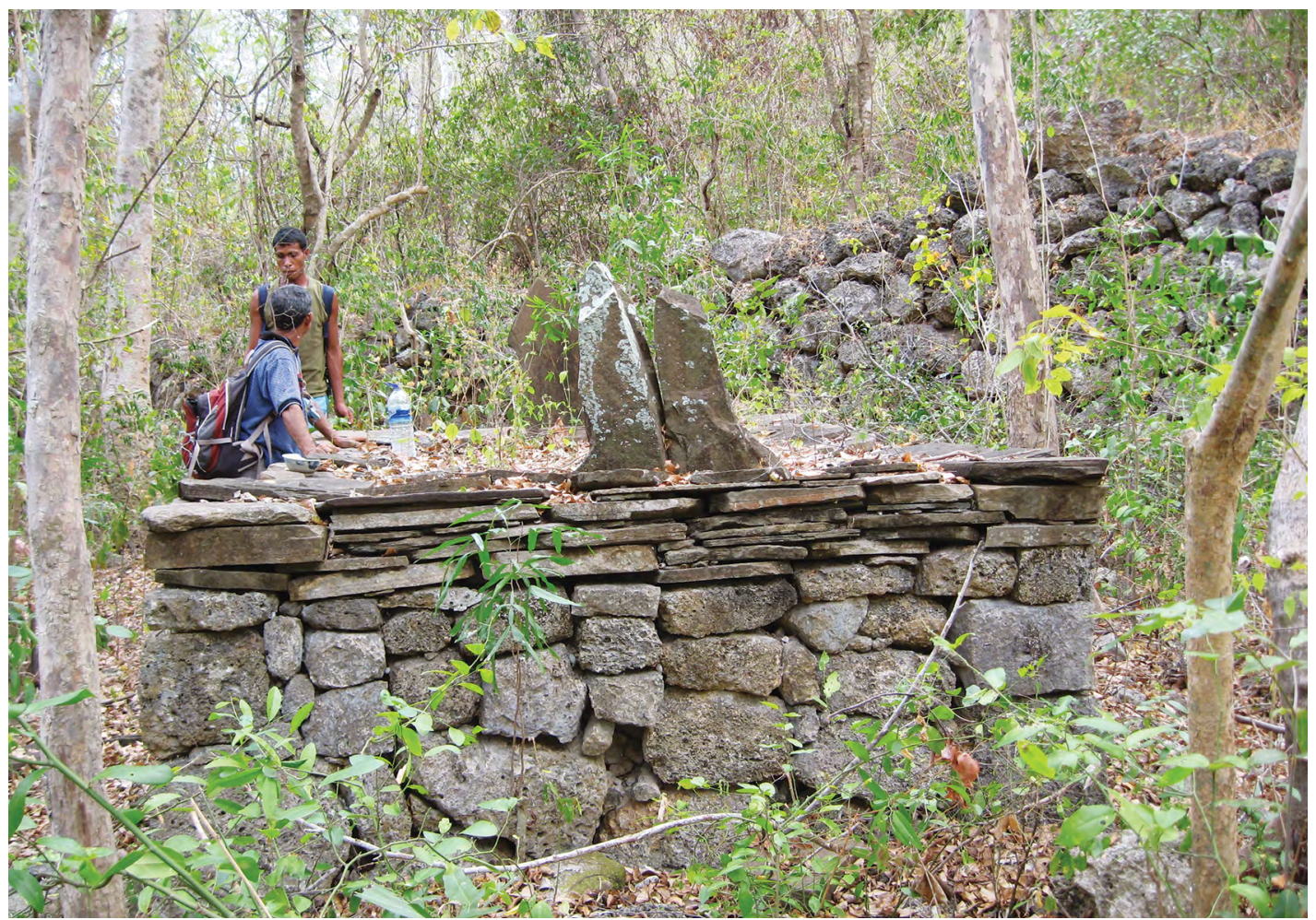

Figure 2.3. Double grave at Macapainara.

Source: Photo courtesy of Sue $0^{\prime}$ Connor.

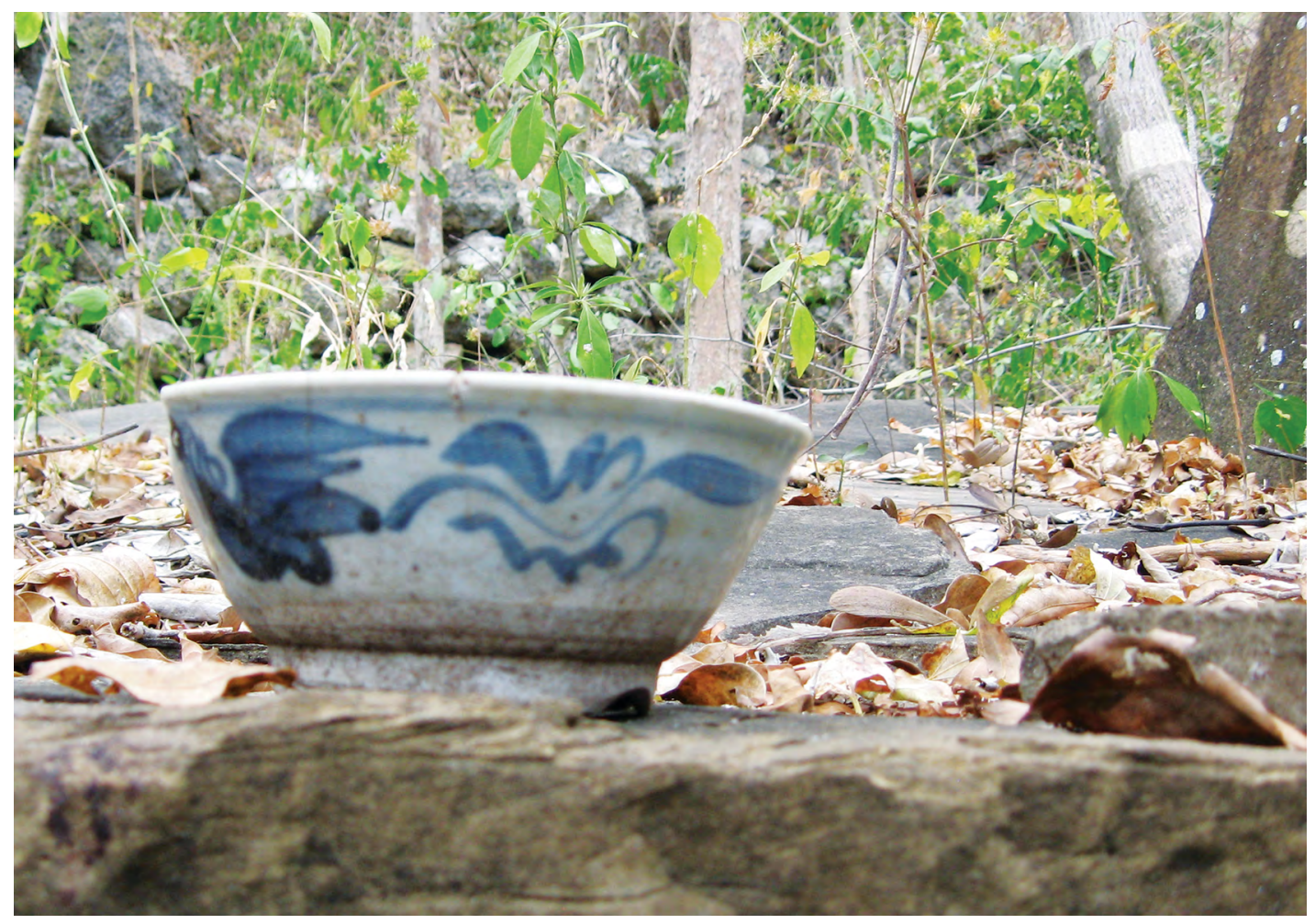

Figure 2.4. Chinese Blue and White tradeware.

Source: Photo courtesy of Sue $0^{\prime}$ Connor. 
Senior clansmen of the contemporary settlements of Mua Pusu and Loho Matu, in the village of Com, recall in their oral histories a time when they lived at Macapainara. During this period, they were actively engaged in inter-island exchange networks, including lucrative trade in sandalwood and human slaves. According to oral histories of the area there was a strong relationship between endemic warfare, the maintenance of fortified settlements and the enslavement of rival communities. Control over the strategic anchorages of the coast enabled them to benefit from the flow of high-value trade goods, especially muzzle-loader firearms, ammunition and gunpowder, while acting as intermediaries with hinterland groups trafficking in war captives and slaves.

In the process, the coastal groups grew rich and contributed to their reputation as Orang Kai. This was a widely used term across the Malay trading world, including the neighbouring islands of the Moluccas, where the Orang Kaya represented an oligarchy of elders from small but wealthy communities who had established a 'mercantile aristocracy' (see Goodman 1998; McWilliam 2007; Villiers 1981:728-729).

\section{Excavation at Macapainara}

Macapainara was excavated over a four-week field season in July-August 2008. A wide variety of cultural materials were recovered, consistent with the oral traditions relating to the age and use of the site, including earthenware, imported tradeware and glass (comprising vessel fragments and beads). Also recovered - and less expected — were a quantity of modified flaked stone artefacts. Subsistence remains included a variety of wild and domesticated terrestrial animal species, fish, shellfish and sea urchin. Small quantities of worked shell and bone were also recovered, demonstrating that decorative items were made at the site using locally available materials. Charcoal was found throughout the excavation and was used for dating the deposit.

Excavations of three 1 x $1 \mathrm{~m}$ squares (A, C and D) reached a depth of c. $1.6 \mathrm{~m}$, when culturally sterile sediment was encountered, showing that sediment accumulated rapidly during the period the site was occupied (Figure 2.5). Excavation occurred in arbitrary spits between $5 \mathrm{~cm}$ and $10 \mathrm{~cm}$ in thickness. All excavated sediment was dry sieved through $3 \mathrm{~mm}$ sieves and finds were sorted at the site. Cultural material was returned to The Australian National University (ANU) for further analysis and remains in the quarantine facility at the Department of Archaeology and Natural History.

\section{Stratigraphy}

The Macapainara deposits consist of pale grey to light grey-brown, poorly sorted, fine to medium sandy silty gravels and medium to coarse gravelly silts. There is near horizontal bedding, with grading from coarser to finer thin beds, and infrequent thin lenses. Gravel size clasts are typically 50-150 mm sub-angular to sub-rounded limestone. Angular shale clasts up to $180-260 \mathrm{~mm}$ occur occasionally. Throughout the sequence, gravels are matrix supported, with most elongate and planar clasts laid sub-horizontal, and showing only slight preferred orientation and no consistent dip. 


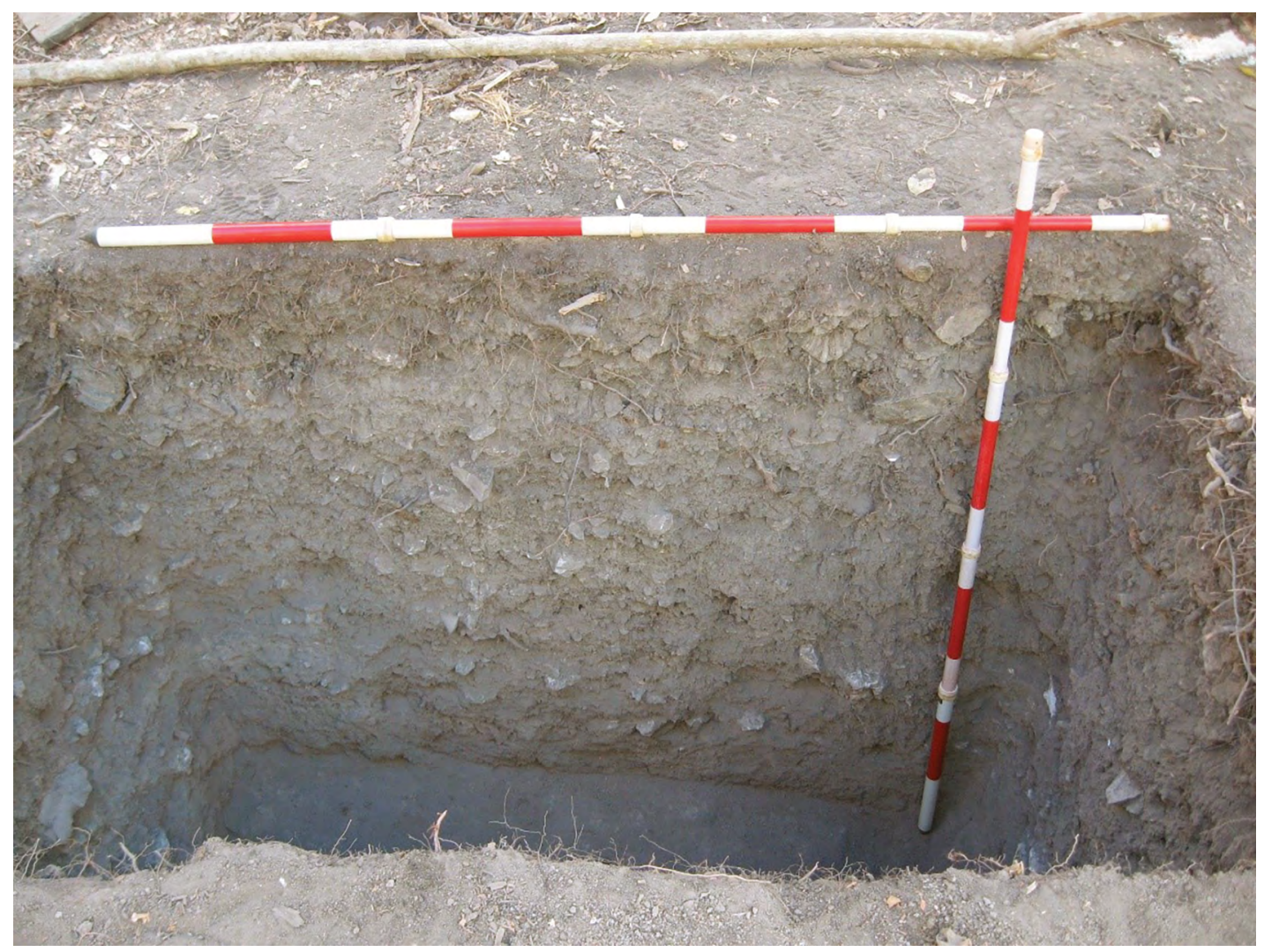

Figure 2.5. South section of Squares C and D, Macapainara, showing stratigraphic units.

Source: Photo courtesy of Sue $0^{\prime}$ Connor.

There is limited pedogenic development. A modern humic topsoil (5-7 cm Ao horizon with leaf litter) has developed, capping a $15-20 \mathrm{~cm}$ zone with abundant modern rootlets. The stratigraphy is consistent with the sequence ages, indicating ongoing accumulation of over $1.5 \mathrm{~m}$ of deposit over 300 years, with numerous artefacts and dumped settlement refuse within the coarser fabric of all layers. The fine to coarse banding probably reflects episodic in-wash, bringing poorly sorted, collapsed and reworked settlement debris and refuse deposits (and possibly some reworked colluvium) short distances into the depocentre. Walls and layout of other built structures have probably confined the locus of deposition, leading to relatively fast net accumulation. The $1.5 \mathrm{~m}$ deep cultural sequence sits, probably unconformably, over an undulating contact onto denser, lighter yellow-brown, clayey sandy silts. This basal unit comprises a bioturbated earlier soil land surface and is largely devoid of coarser gravel clasts.

\section{Chronology of occupation}

Nine accelerated mass spectrometry (AMS) radiocarbon dates on charcoal were obtained from throughout the deposit at Macapainara (Table 2.1; Fenner and Bulbeck 2013). Only charcoal radiocarbon dates are included because the carbon reservoir offset for marine shell $(\Delta \mathrm{R})$ is unknown for this area. Bayesian analysis of the nine results indicates Macapainara was probably first occupied between AD 1695-1780, and likely postdates AD 1600 (97 per cent probability). It was not abandoned until the mid-twentieth century or later. 
Table 2.1. Radiocarbon dates from Macapainara from Squares A, C and D.

\begin{tabular}{|l|l|l|l|}
\hline Sample & Lab ID & Radiocarbon date (RCYBP) & Calibrated range (year AD) \\
\hline A2C & WK24947 & $54 \pm 30$ & 1809 to 1837,1845 to 1858,1880 to 1922 \\
\hline A8C & WK24948 & $8 \pm 30$ & 1806 to 1840,1842 to 1867,1876 to 1923 \\
\hline A13C & WK24949 & $221 \pm 30$ & $\begin{array}{l}1666 \text { to } 1683,1725 \text { to } 1814 \\
1836 \text { to } 1849,1855 \text { to } 1879\end{array}$ \\
\hline C2C & WK24950 & $107 \pm 30$ & 1804 to 1923 \\
\hline C7C & WK24951 & $72 \pm 30$ & 1808 to 1839,1844 to 1866,1878 to 1923 \\
\hline C13C & WK24952 & $282 \pm 30$ & 1644 to 1665,1739 to 1801 \\
\hline D2C & WK24953 & $49 \pm 30$ & 1809 to 1838,1880 to 1922 \\
\hline D8C & WK24954 & $193 \pm 37$ & 1721 to 1897,1920 to 1932 \\
\hline D15C & WK24955 & $93 \pm 30$ & 1806 to 1870,1876 to 1924 \\
\hline
\end{tabular}

Calibrations and Bayesian analysis were performed using the BCal calibration program (Buck et al. 1999) with the SHCal04 calibration curve (McCormac et al. 2004). Calibrated date ranges shown are the 95 per cent highest probability density regions. Source: Adapted from Fenner and Bulbeck (2013: Table 1).

\section{Methods}

\section{Glass beads and sherds}

The majority $(\mathrm{N}=11)$ of the total excavated glass beads and sherds were analysed from Macapainara, using laser-ablation-inductively coupled plasma-mass spectrometry (LA-ICP-MS) (see Lankton and Gratuze 2011 for more detailed methods).

\section{Earthenware}

The entire Macapainara earthenware assemblage was inspected twice by David Bulbeck, and a further petrographic analysis was undertaken by William R. Dickinson. During the first inspection, a Microsoft Access database was created to record the pottery in detail. The Access 'parent' table, 'vessel', was created to record information that went beyond the individual sherd, such as cases of multiple sherds that had evidently fragmented from the same originally deposited pot, or cases where the sherd(s) assigned to a pot were diagnostic as to the pot's original vessel form. A second Access parent table, 'sherd', allowed for observations at the level of the sherd or group of similar sherds, with links to supplementary observations in Access 'child' tables on rim, neck, shoulder, footring and basal sherds, as well as slipped sherds and decorated sherds. Not every sherd was individually recorded, and instead unslipped body sherds were classified into a 'sherd' group (e.g. 'Spit A3 "Brown", externally reduced, internally and externally smoothed, with traces of paddle and anvil manufacture'), and a representative sherd from each group was recorded in the Access database.

Over 6,600 'sherd' observations were made, whether these were observations of individual sherds, multiple sherds from the same vessel (and vessel part) found in the same spit, or a representative sherd from a 'sherd' group. Observations included the number of sherds involved, their weight to the nearest tenth of a gram, internal and external Munsell colours, and signs of surface finish. Additional observations for rim sherds included their orientation as everted, direct or inverted (following Shepard 1974); if everted, whether the rim section was short, long or indeterminate, particular rim shape characteristics, and (where possible to estimate) approximate rim diameter. Neck sherds (which often were also rim sherds) were recorded as having a profile that was sharp, 
rounded or indeterminate, and shoulder sherds as sharply or less sharply carinated. Footring and basal sherds were recorded according to their shape based on the variability noted during the first inspection of the assemblage.

\section{Tradeware}

The 67 tradeware sherds excavated from Macapainara were studied in detail so as to infer the probable form of the parent vessel and the parent vessel's place of manufacture (according to the categories used in the literature on trade ceramics). About three-quarters of the classifications are Chinese, and these are notified in terms of the finer categories 'Guangdong', 'Ming', 'Transitional', 'Zhangzhou' (formerly known as Swatow), 'Kraaksporselein', and 'Qing' (which includes wares dated to the Yongzheng reign). Zhangzhou wares were classified into 'Ming Zhangzhou', 'Zhangzhou' and 'Qing Zhangzhou', following the classification system developed for these wares in South Sulawesi, where Zhangzhou (Swatow) sherds abound (Bulbeck 1992). The dates for the Zhangzhou subclassifications are taken from Bulbeck (1996-97) except where finer chronological matches are available from the literature.

The term 'porcelain' is restricted to sherds with a translucent body, as determined by shining a small torch through the sherd's wall. The only true porcelain sherds excavated from Macapainara were Chinese. Three Chinese sherds and one Vietnamese sherd were also identified as 'semiporcelain', which indicates marginal translucency and/or a pinkish rather than pure white body. Sherds from similarly high-fired vessels with a fine fabric virtually free of inclusions, but which are opaque rather than translucent-such as the so-called porcelains exported in mass from European factories during the colonial era-are identified as 'fine stoneware'. 'Stoneware', where not qualified as fine, refers to coarser fabrics that may be strongly tinted, such as the fabrics found in large, coarse stoneware jars (martavans).

Bulbeck conducted further analyses, the results of which are available in Bulbeck (2012), including fabric identification and the colour of the body and glazed surface, which was recorded using a Munsell soil colour chart. Approximate hardness of the body was tested by the 'scratch test' with a quartz crystal and, for any fabric softer than quartz, a steel knife blade. An estimate was made of the approximate percentage of the fabric composed of inclusions, primarily with reference to the exposed surface but taking into account the weathered body surface. The weights of the tradeware sherds were measured to the nearest 0.01 of a gram, the maximum body thickness recorded to $0.1 \mathrm{~mm}$, and the colours of any decorations were recorded using a range of Munsell colour charts, by default the soil colour chart when a match could be found. Documentation of the sherds in Bulbeck (2012) also includes discussion of which sherds could be assigned to the same parent vessel and a description of the basis for each tradeware classification.

\section{Stone artefacts}

Stone artefact analysis involved an initial inspection and count of specimens. The quantity of artefacts is surprising in view of the historical context of the site (Table 2.1), and it is assumed that stone would have been 'abandoned as an important tool-making material at least 2,000 years ago' following the introduction of metal (Glover 1986:202). For this reason, a set of nominal variables were employed to confirm the veracity of artefact identification, following methods employed in the analysis of the Lemdubu assemblage from the Aru Islands (Hiscock 2007:210). Variables included the presence of a striking platform, bulb of percussion, negative flake scars, external initiation and flake termination; these, in combination, support artefact identification. 
To establish whether cores were reduced onsite (as opposed to being imported from outside and potentially older sites), reduction variables such as core rotations, number of flake scars, and flake cortex types were recorded, following Marwick (2008). To quantify the intensity of retouched flake reduction, the Average Geometric Index of Unifacial Reduction (AGIUR) was also recorded (Kuhn 1990).

One explanation for the stone artefact assemblage at this fort site is a strike-a-light tool industrywhere siliceous stone flakes are marginally retouched, usually with metal implements, for the sole purpose of creating sparks for fire-lighting (e.g. Glover and Ellen 1975:52-53). The use of strikea-lights is widely reported from Island Southeast Asia (Brumm 2006; Glover 1986:202; Glover and Ellen 1975; Pannell and O'Connor 2005:201; Scheans et al. 1970:180; Skertchly 1890:450, 451). From these studies a set of characteristic edge modification variables were employed to test the likelihood of this function. The use of metal objects as percussors will likely create marginal concentrations of step fractures, crushing or cascading, bifacial battering, dense striations and typically minimal retouch before discard (Andrefsky 2009:196; Brumm 2006:169-170; Glover and Ellen 1977; Staperd and Johansen 1999:768). Notably, one study has shown that even when individual flakes are observed in strike-a-light activities, apparent characteristic modification variables, particularly striations, may not be present (Brumm 2006:170). Nonetheless, each artefact was examined for these characteristics.

\section{Vertebrate faunal remains}

Distinctive vertebrate elements were identified to family, genus or species using the modern comparative reference collection and digital database housed at the Archaeological Studies Program, University of the Philippines. The maximum lengths of all fragments greater than $5 \mathrm{~mm}$ were measured, unless they showed evidence of modern breakage, to identify any spatial and temporal variability in fragment size that might provide information on taphonomic process. Taphonomic terminology follows Piper (2006) modified from Lyman (1994). Important taphonomic and anthropic alterations, including weathering, burning, dog gnawing and butchery marks were recorded.

The criteria used for the biometric analyses of post-cranial elements follow von den Dreisch (1976). Whenever applicable, alternative measurements from diagnostic anatomical locales were used. Features that might indicate defects, for instance bone regrowth/pathologies, were also recorded. For caprine and suid teeth, a standard measurement for the length of the tooth was taken, and then the width of each molar column measured. All measurements were taken at, or as close to, the base of the enamel as possible. Since goat and pig teeth change shape as they wear, this location provides a point of reference where the analyst can be confident that all measurements of archaeological and comparative specimens will be comparable. To compensate for inter-analyst preferences, the lengths of the pig M1s and M2s were also measured at the occlusal surface (in brackets in Tables 5 and 6 of Piper and Amano 2011) so that they can be compared irrespective of which measurement has been used by other specialists. Pig ageing from molar eruption and post-cranial fusion follows Bull and Payne (1982), and molar wear scales are based on those presented by Grant (1982).

All teeth and bones with key taphonomic and anthropic modifications and other selective elements were photographed and archived using a Nikon Coolpix Digital camera. Micrographs were also taken using the same camera mounted on a Nikon C-LEDS stereomicroscope. 


\section{Invertebrate faunal remains}

All shells and shell fragments were identified to the lowest possible taxonomic level through the use of ANU and Museum and Art Gallery of the Northern Territory malacology collections. Sea urchin was weighed. The shell assemblages were quantified by weight $(\mathrm{g})$, minimum number of individuals (MNI) and number of identified specimens present (NISP) for each of the three excavations squares (A, C and D). Weight, MNI and NISP were calculated in an attempt to assess potential biases inherent in each. The MNI method, which quantifies one repetitive feature per taxon throughout an assemblage, avoids the fragmentation bias inherent in the NISP technique and other biases associated with the sole use of weight to quantify taxon through time (Classen 1998), and for this reason is used as the primary mode of quantification.

The repetitive features or elements selected throughout the Macapainara assemblage are: the posterior valve for chitons, apices for gastropods, and for bivalves, both left and right hinges were counted, with the greater number selected (following Classen 1998). All shell was counted and weighed within excavation spit divisions. In spits where a taxon was present, but the repetitive element was absent, the MNI is noted as ' $<1$ ', to avoid overestimation of that taxon for the entire square. It should be noted that while Turbo sp. and Nerita sp. opercula were quantified during laboratory analysis, opercula counts are excluded from all aggregative calculations, to avoid inflating representation of the Turbinidae and Neritidae families. Shell reduction patterns were noted during analysis. Some species in particular showed repetitive reduction or damage patterns suggestive of their use for artefact manufacture.

\section{Organic artefacts}

The shell artefacts were photographed with a Canon digital SLR camera. Identification of manufacture and use traces was based on previous analyses of marine shell technologies (e.g. Bar-Yosef Mayer 2005; Cristiani et al. 2014; d'Errico et al. 1993; Langley and O'Connor 2015, 2016; Stiner et al. 2013; Szabó 2010; Vanhaeren et al. 2013). Bone artefacts were identified during the vertebrate faunal analysis and are described in the results, although a detailed use-wear analysis has yet to be undertaken.

\section{Results}

\section{Glass sherds and beads}

Across squares, Spits 1 to 5 produced 21 sherds from glass vessels (Table 2.2). Six representative examples were sent to James Lankton in 2009 for chemical analysis. Lankton and Gratuze (2011) report that all of them were very high in lime and alumina and moderate in magnesia. Their composition indicates they were made using oak ash as the source of flux, producing a type of glass common in Europe from the seventeenth to nineteenth centuries.

Spits 2 to 14 yielded a small assemblage of seven glass beads $(2 \mathrm{~g})$, of which five were sent to Lankton for chemical analysis (Figure 2.6). Four of the seven beads appear to be of Chinese production, best dated to between the sixteenth and eighteenth centuries. Two beads have tentative European parallels, while one appears to be an Indo-Pacific bead. Although the production of Indo-Pacific beads was largely wound up by $\mathrm{AD} 1200$, these beads remain in circulation till today as heirloom jewellery in Timor-Leste and the Indonesian province of Nusa Tenggara Timur, including West Timor (Francis 1999:94-95). Accordingly, the Indo-Pacific bead at Macapainara could be from an heirloom, and so its identification does not necessarily contradict the sixteenth- to eighteenthcentury dating suggested by the Chinese beads. 


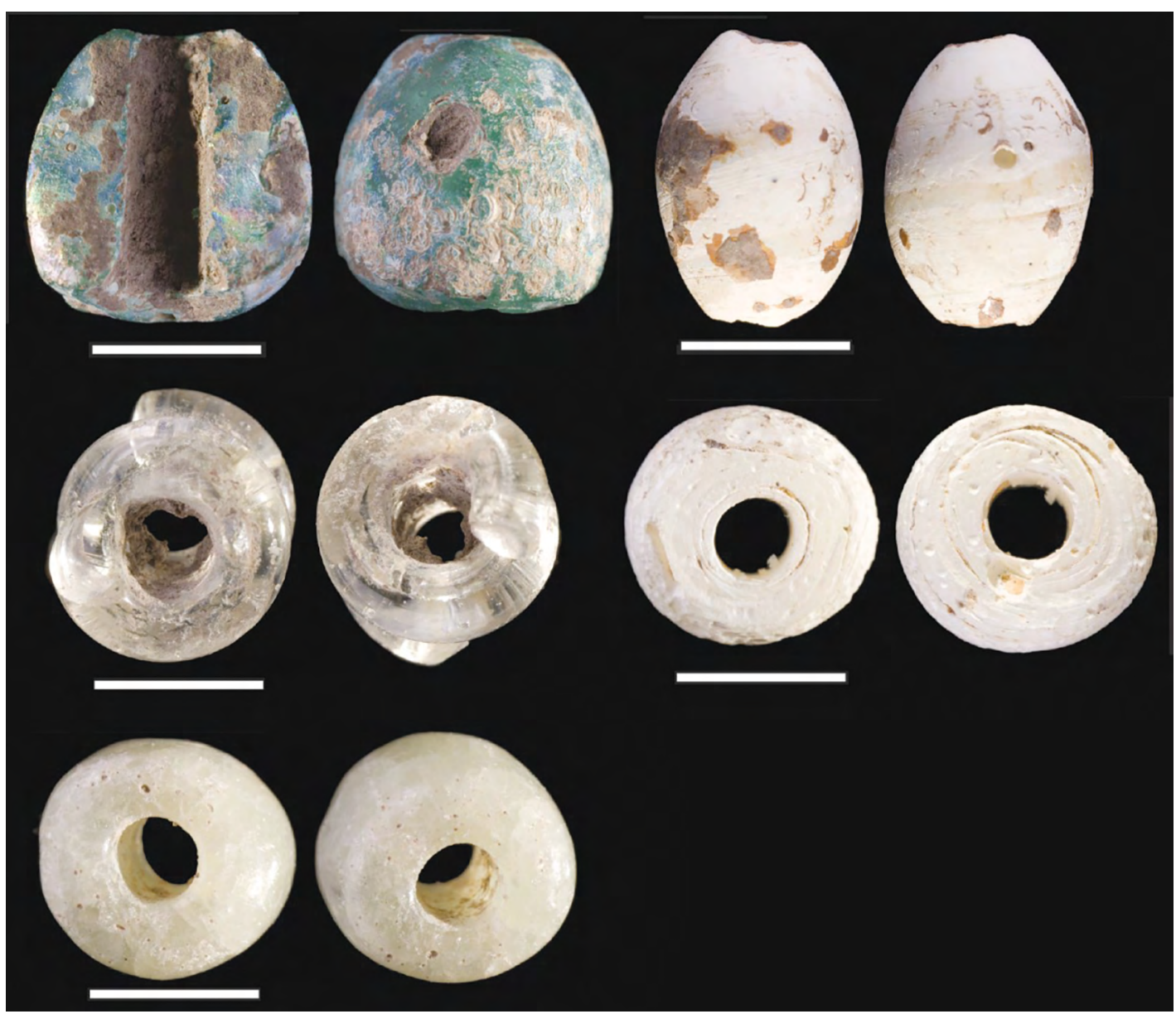

Figure 2.6. Glass and shell beads from Macapainara (sample).

Source: Photo courtesy of Mirani Litster.

Table 2.2. Distribution of Macapainara glass and tradeware.

\begin{tabular}{|l|c|c|c|c|c|c|c|c|c|}
\hline Material & \multicolumn{2}{|c|}{ Vessel/container glass pieces } & \multicolumn{3}{|c|}{ Glass beads } & \multicolumn{3}{c|}{ Tradeware sherds } \\
\hline Squares & A & C & D & A & C & D & A & C & D \\
\hline Spit 1 & 4 & - & 8 & - & - & - & 1 & - & 1 \\
\hline Spit 2 & 4 & 2 & 1 & - & 2 & - & 7 & 6 & 3 \\
\hline Spit 3 & - & - & - & - & - & - & 4 & - & - \\
\hline Spit 4 & - & - & - & - & 1 & - & 2 & 1 & 3 \\
\hline Spit 5 & 2 & - & - & - & - & 1 & 1 & - & 3 \\
\hline Spit 6 & - & - & - & - & - & - & - & - & - \\
\hline Spit 7 & - & - & - & - & - & - & 7 & - & 2 \\
\hline Spit 8 & - & - & - & - & - & 1 & - & 1 & 2 \\
\hline Spit 9 & - & - & - & - & - & - & 2 & 2 & 3 \\
\hline Spit 10 & - & - & - & - & - & - & 5 & 4 & 1 \\
\hline Spit 11 & - & - & - & - & - & - & 1 & 2 & 2 \\
\hline Spit 12 & - & - & - & - & - & - & - & - & - \\
\hline Spit 13 & - & - & - & - & - & - & - & 1 & - \\
\hline Spit 14 & - & - & - & - & - & 2 & - & - & - \\
\hline
\end{tabular}

Source: Authors' summary.

\section{terra australlis 53}




\section{Earthenware}

Close to 1.3 per cent $(32 \mathrm{~kg}$ ) of the excavated sediment (excluding excavated rocks) constituted pottery. Square A yielded around $7 \mathrm{~kg}$, Square C $11 \mathrm{~kg}$ and Square D $14 \mathrm{~kg}$, making up between 0.9 per cent and 1.5 per cent of the excavated sediment in these squares. The upper spits tended to yield the most pottery: for instance, Spits 2 to 4 in Square A, Spits 3 to 7 in Square C and Spits 4 to 7 in Square D. Some $2.88 \mathrm{~kg}$ or around 9 per cent of the pottery (by weight) is decorated (e.g. Figure $2.7 \mathrm{a}-\mathrm{e}$ ). Square $\mathrm{C}$ has a lower proportion of decorated sherds. In every square, Spits 7 and 8 yielded an above-average proportion of decorated sherds. The most common form of decoration is paddle-impressed: vertical lines $(1.4 \mathrm{~kg})$, rectangular impressions $(992 \mathrm{~g})$, horizontal lines $(32 \mathrm{~g})$ and curvilinear lines $(30 \mathrm{~g})$. Rare forms of decoration include some $156 \mathrm{~g}$ with abstract painted decorations (see Figure 2.7b-d), incisions (horizontal, vertical, slanting and curvilinear lines; triangles, commas and chevrons, $94 \mathrm{~g}$ altogether), impressions (quadrilateral, rectangular and reniform, $68 \mathrm{~g}$ altogether), notched and appliqué corrugations $(52 \mathrm{~g})$, rectangular and slanting notches $(13.5 \mathrm{~g}$ together) and vertically gouged lines $(15 \mathrm{~g})$. Temper types often consisted of foraminiferal calcareous grains, variably combined with a dominant element of massive terrigenous grains or limeclast calcareous grains.

The great majority of assignments of sherds to a parent vessel involved sherds from the same spit, but many assignments involving sherds from different spits were also made (Figure 2.8). Most pairs of adjacent spits in Square A contained sherds that were assigned to a single parent vessel, and the same was true for many pairs of adjacent spits (sometimes ranging across three spits) in Squares $\mathrm{C}$ and $\mathrm{D}$. There were also several cases of the adjacent $\mathrm{C}$ and $\mathrm{D}$ Squares yielding sherds assigned to the same parent vessel.

Just over 5 per cent $(1.7 \mathrm{~kg})$ of the Macapainara sherdage was recorded as slipped, including 5.9 per cent (of $5.5 \mathrm{~kg}$ ) of rim sherdage, 2.4 per cent (of $5.6 \mathrm{~kg}$ ) of neck sherdage, 6.8 per cent $(880 \mathrm{~g}$ ) of shoulder sherdage, and 6.0 per cent (of $18.6 \mathrm{~kg}$ ) of the body sherds. Slips were applied slightly more often to external surfaces (76 per cent, including sherds slipped on both surfaces) than internal surfaces (65 per cent, including sherds slipped on both surfaces). Red slips were dominant (62 per cent), but brown slips (11.2 per cent), black slips (13.2 per cent) and white slips (12.5 per cent) were also recorded. Red slips included a distinctive, dark red burnished slip, notable in the Vasino assemblage, but observed on just $178 \mathrm{~g}$ of the Macapainara sherdage, mainly in Spits 11 to 15 (158 g). Addition of resin to the applied coat often appeared to be the factor responsible for the brown-slipped effect, as sometimes observed on the black-slipped surfaces (which appeared carbonised and polished). White slipping, more characteristic of internal than external surfaces, may have been achieved by application of calcareous-rich clay.

The most commonly recorded external surface colours were grey ( $16.9 \mathrm{~kg}, 53$ per cent) and brown (13.8 kg, 43 per cent). The grey sherds were frequently dark grey $(5.2 \mathrm{~kg}, 16.3$ per cent) and very dark grey ( $4.3 \mathrm{~kg}, 13.4$ per cent), usually associated with reducing firing conditions, but also often pinkish grey $(2.1 \mathrm{~kg}, 6.6 \mathrm{per}$ cent), reddish grey $(1.3 \mathrm{~kg}, 4.1 \mathrm{per}$ cent $)$ and light brownish grey $(1.2 \mathrm{~kg}, 3.8$ per cent), associated with a more oxidising firing environment. Commonly recorded variants of the brown sherds were reddish brown $(3.8 \mathrm{~kg}, 27.5$ per cent), light reddish brown ( $2.3 \mathrm{~kg}, 16.7$ per cent) and greyish brown $(2.7 \mathrm{~kg}, 19.6$ per cent), in the last case verging on the grey sherds in their colour. Rare surface colours included black (567 g, 1.8 per cent), red (129 g, 0.4 per cent), reddish yellow ( $40 \mathrm{~g}, 0.1$ per cent) and white $(24 \mathrm{~g}, 0.1$ per cent). 


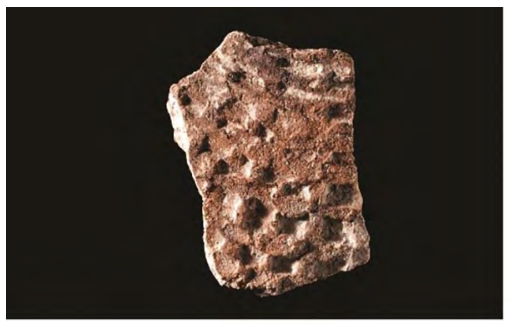

(a)
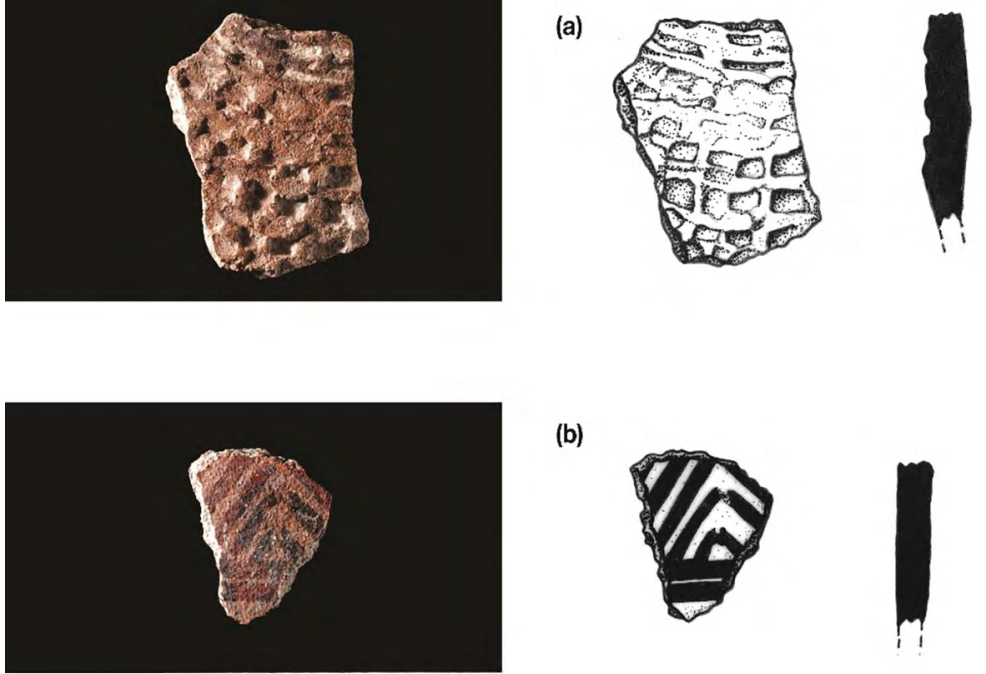

(b)
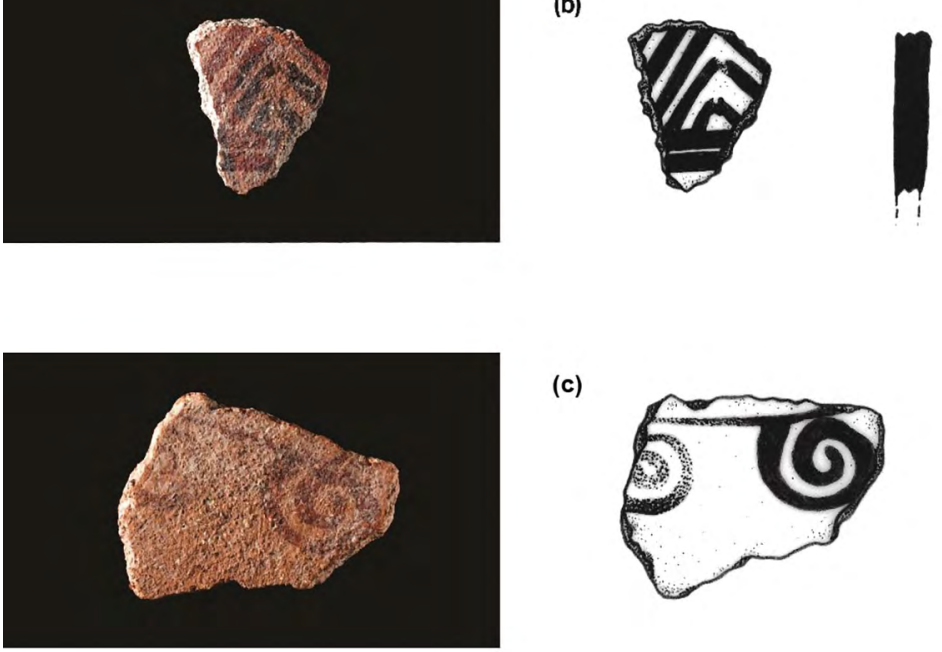

(c)
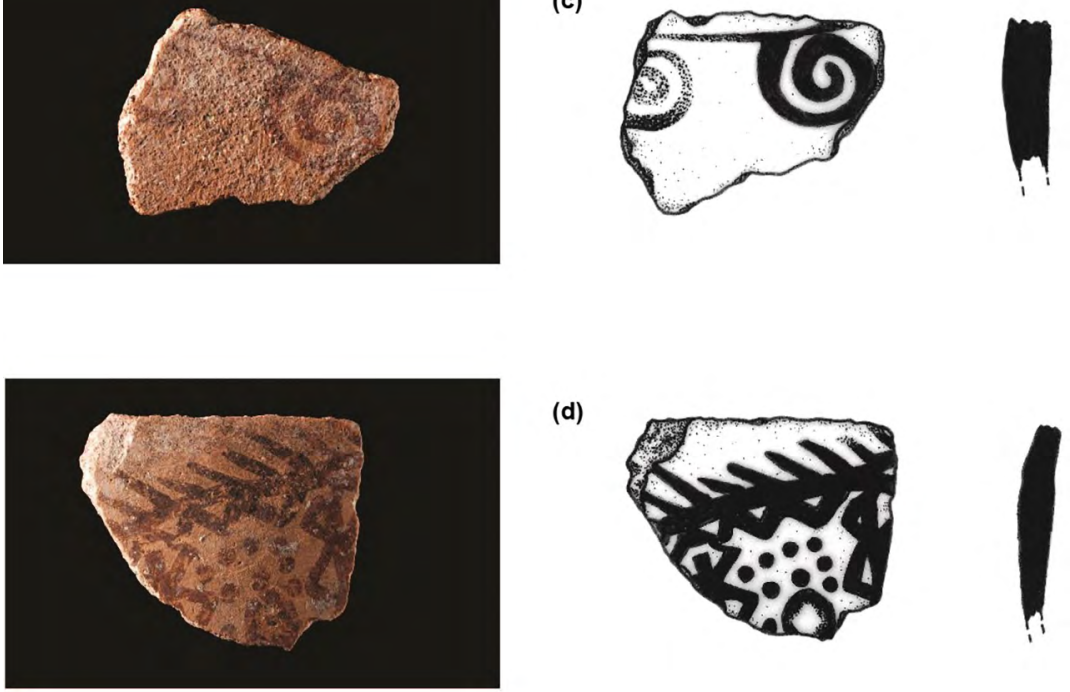

(d)
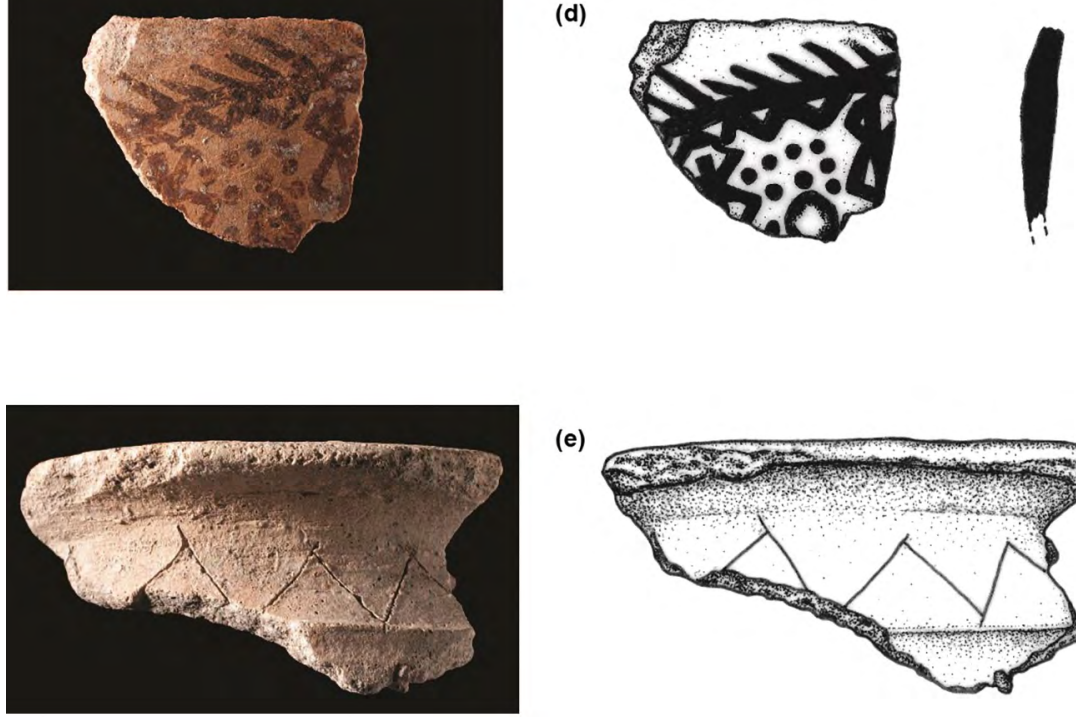

(e)
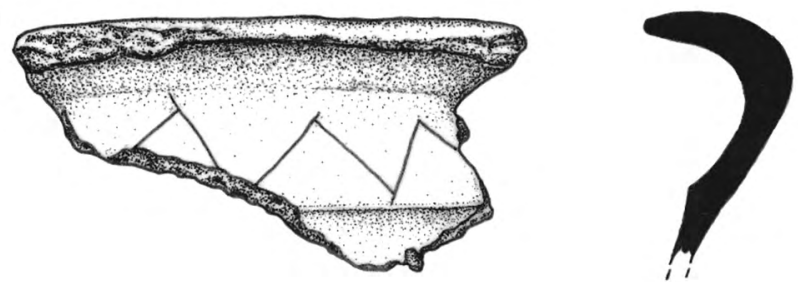

Figure 2.7. Decorated sherds from Macapainara.

Source: Photos and drawings courtesy of Virginia Das Neves. 


\begin{tabular}{|c|c|c|c|}
\hline & Square $\mathrm{A}$ & Square C & Square $D$ \\
\hline Spit 1 & 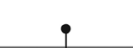 & $\bullet$ & 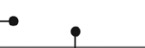 \\
\hline Spit 2 & $\dot{0}$ & - . & - \\
\hline Spit 3 & ? & $\bullet$ & : \\
\hline Spit 4 & : & $: \quad:$ & p \\
\hline Spit 5 & : & $\cdot$ & : \\
\hline Spit 6 & ! & & : \\
\hline Spit 7 & $\bullet$ & - & $\cdot$ \\
\hline Spit 8 & $\bullet$ & - & - \\
\hline Spit 9 & ? & & ? \\
\hline Spit 10 & ? & $\circ \quad \circ$ & $\bullet$ \\
\hline Spit 11 & : & $\because$ & $\because:$ \\
\hline Spit 12 & : & . & ? \\
\hline Spit 13 & ? & & ! \\
\hline Spit 14 & ! & & $: \quad:$ \\
\hline Spit 15 & - & & 6 \\
\hline Spit 16 & No pottery & & - \\
\hline
\end{tabular}

Figure 2.8. Recognised Macapainara vessels with sherds from separate spits.

Source: David Bulbeck.
The Macapainara externally red-slipped sherds accounted for most of the redcoloured sherds and also a proportion of the reddish brown (including light and dark reddish brown) sherds. In addition, $1.5 \mathrm{~kg}$ (4.7 per cent) of the sherds were recorded as externally self-slipped, typically associated with a reddish brown colour. The externally black-slipped, brown-slipped and whiteslipped sherds were respectively associated with black or other dark colours, reddish brown or reddish grey, and whitish colours. In addition to the externally slipped and selfslipped sherds, a further $2.0 \mathrm{~kg}$ (6.2 per cent) of the Macapainara sherds were externally smoothed. Wiping marks were visible on both faces of approximately 12 per cent of the assemblage, external wiping marks on some 26 per cent, and internal wiping marks on some 8 per cent of the assemblage.

No wasters were recorded to indicate pottery manufacture at Macapainara itself. Blistered external and/or internal surfaces suggestive of overfiring were recorded on only $350 \mathrm{~g}$ (1.1 per cent) of the assemblage. The sherds appeared to be fully oxidised for $14.0 \mathrm{~kg}$ (43.8 per cent) of the assemblage, although surface clouds and smudges from firing were recorded on a further $4.7 \mathrm{~kg}$ (14.7 per cent), and evidence of grey or dark cores on a further $626 \mathrm{~g}(-2$ per cent). Internally or externally reduced surfaces, occurring together or in combination with a reduced internal wall, were recorded for $13.7 \mathrm{~kg}$ ( 42.1 per cent) of the assemblage, including $1.8 \mathrm{~kg}$ ( 5.6 per cent) where the sherd was reduced entirely. The above observations in most cases would reflect firing conditions for the vessels during their manufacture, although in some cases post-manufacture exposure to heat (such as an open fire) may have left surface clouds and/or similar visual effects to earthenware vessels fired in a reducing environment.

\section{Ceramic forms, rim shapes and manufacturing techniques}

Ceramic form could be determined for 287 vessels, as well as one cylinder and five flat discs. Most or all of these ceramic products would be distinct individual items (comparable to MNIs in faunal analysis) and the true number represented by the assemblage would be much greater than 293. The majority of ceramic items were classified as jars (83 per cent) on the basis of possessing a neck and everted rim. Most of these appeared to be medium-sized jars ( 71 per cent of ceramic items) with a rim diameter between 11 and $19 \mathrm{~cm}$. A smaller number appeared to be small jars ( 2 per cent of items) with a rim diameter up to $10 \mathrm{~cm}$, or large jars (10 per cent of items) with a rim diameter of at least $20 \mathrm{~cm}$. One use of the medium-sized jars may have been 
as cooking pots, although only $300 \mathrm{~g}$ of the Macapainara sherds preserved carbonised traces on their surfaces. The large jars were presumably used as storage vessels. Just 2 per cent of the jars appear to have been covered, and only four sherds apparently from cover handles were identified.

Apparent serving vessels with an unrestricted rim were classified as plates (6 per cent), most of which had an everted foot, and bowls ( 4 per cent), some equipped with a footing. Three footed vessels were identified as having a distinctly carinated shoulder and constricted rim and may have been used for the slow burning of incense or other aromatic substances. Other rare forms included two squarish boxes, two apparent stoves (large vessels lacking curvature) and six crucibles (identified by their tough earthenware fabric, apparently exposed to very high temperatures, direct pointed rim and/or small rounded chamber). The crucible fragments are important evidence for metallurgy at Macapainara.

Jar rim shape showed considerable variability. Rounded (Figure 2.9.A), semi-squared (Figure 2.9.B) and squared (Figure 2.9.C) rims were classified as furrowed if the rim end contained a distinct furrow (Figure 2.9.F) or fattened if the rim end was distinctly expanded (Figure 2.9.G). Sharpended rims included triangular (Figure 2.9.D) and pointed (Figure 2.9.E) varieties. Distinctly upturned rims were classified as upturned (Figure 2.9.H) regardless of their other shape details. Upturned rims accounted for around a third of the jar rims (by weight), rounded rims a quarter of the jar rims and the variety of other shapes the remainder. In relation to stratigraphy, rounded jar rims predominated in Spits 9 to 15 at Macapainara but dropped to between 9 per cent and 25 per cent in Spits 1 to 8 where the other rim shapes, notably upturned rims, increased in frequency. This rim shape variability may have been in imitation of similar rim shapes found on Chinese and Thai jars and other export ceramics (see Bulbeck 1996-97; Green et al. 1981; Harrisson 1990).

Evidence for pottery manufacturing and finishing techniques was based on the criteria in Rye (1981). Possible evidence of coil-building was observed on just one sherd. Hand modelling was recorded as the forming technique for the cylinder, disc and crucible bodies. Slab building was recorded as the forming technique for the stoves, as well as four plates and six jars. The dark red burnished vessels sometimes appeared to have been manufactured on a fast wheel, as indicated by regular, closely spaced wheel-throwing lines. Similar evidence of fast wheel manufacture was recorded on a medium-sized jar. The most commonly recorded manufacturing techniques, sometimes recorded together on the same vessel, were the use of a slow wheel, mainly at the rim and neck $(3.8 \mathrm{~kg})$ and the paddle-and-anvil technique, mainly on body sherds $(10.9 \mathrm{~kg})$. Where vessel form could be associated with these techniques it was most frequently a medium-sized jar, in line with the predominance of this vessel form in the assemblage. Therefore, the most common production procedure for the Macapainara vessels probably involved shaping the jar with a paddle applied externally (often leaving vertical paddle impressions) and an anvil held inside the wall. 


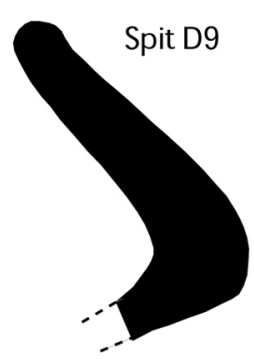

A. Rounded (long rounded)

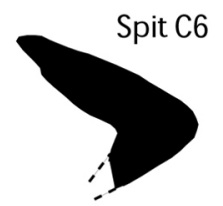

Short semi-squared

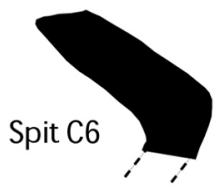

\section{B. Semi-squared}

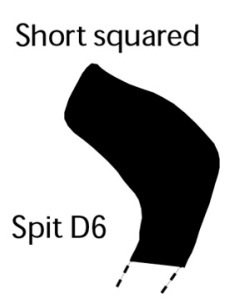

\section{Squared}

\section{Triangular (short triangular)}

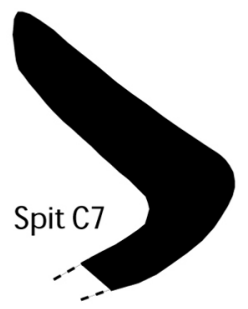

E. Pointed (long pointed)

Short squared fattened

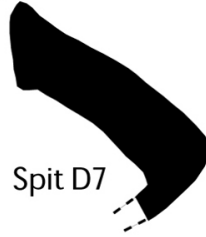

\section{G. Fattened}

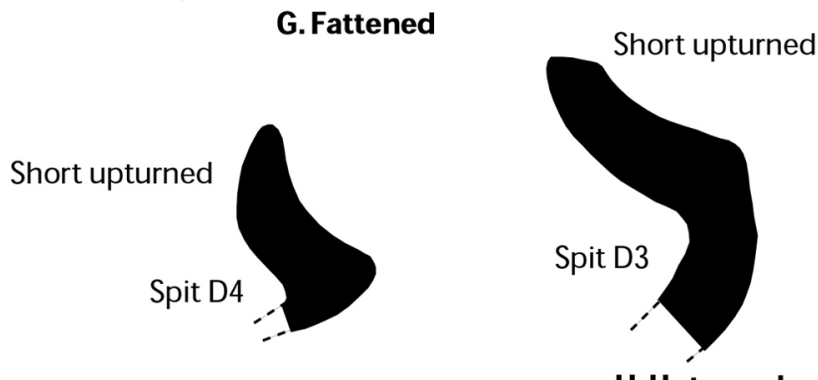

\section{Long rounded fattened}

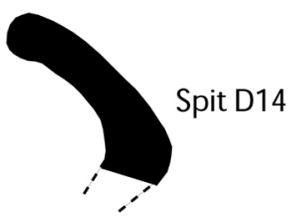

Long semi-squared

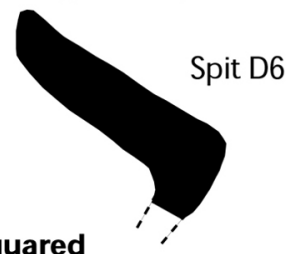

Long squared

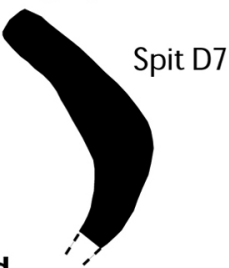

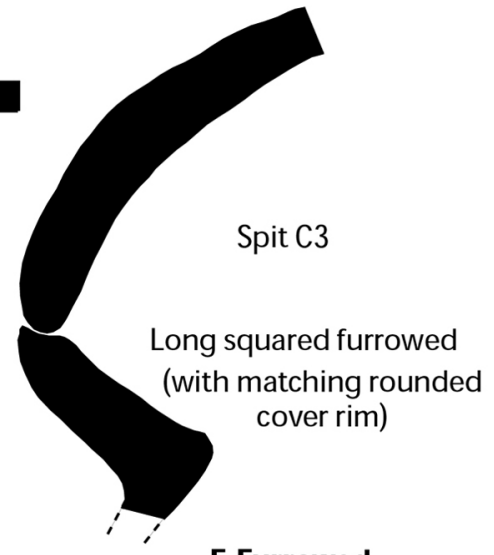

F. Furrowed

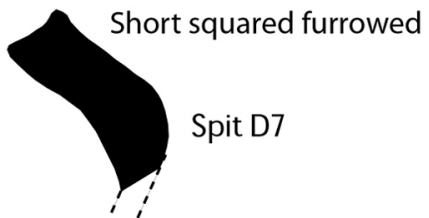

H. Upturned

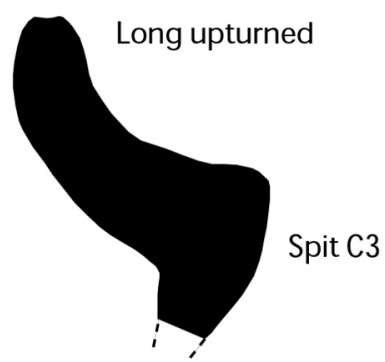

Figure 2.9. Macapainara jar rim shapes.

Source: David Bulbeck. 


\section{Tradeware}

The 67 imported tradeware sherds from Macapainara (Appendix Table 2.A1), weighing $154 \mathrm{~g}$ in total, appear to represent 55 different vessels. Most of the sherds (52-53; c. 78 per cent) are identified as Chinese, with dates between the sixteenth and nineteenth centuries (plus three mid to late second millennium datings). Six Vietnamese sherds dated to between the fifteenth and nineteenth centuries, and possibly all as late as the seventeenth century, were recovered from Spits 3 to 7 . Three European sherds dating to the eighteenth and early nineteenth centuries were excavated in the top two spits and Spit 7. The remaining classes include two Thai (Singburi) storage jars (Spits 2 and 7, sixteenth to seventeenth centuries), two Coarse Brown storage jars from Thailand or Cambodia (Spits 9 and 10, sixteenth to seventeenth centuries), and a Coarse Red jar from Vietnam (Spit 9, seventeenth to eighteenth centuries).

In addition, Square D yielded three bracelet fragments that appear to be low-fired stoneware, of European (perhaps Portuguese) or Brazilian production. Spit 4 produced a pierced bracelet segment (weight $0.35 \mathrm{~g}$ ), and Spit 5 produced two joining fragments from a different polished ceramic bracelet (weight $1.40 \mathrm{~g}$ ).

The entire tradeware assemblage may be dated to between the sixteenth and nineteenth centuries. Some evidence was found for increasing age of the tradeware identifications with depth, as the sherds in Spits 10 to 13 could all date to between the sixteenth and seventeenth centuries (see Appendix Table 2.A1). However, caution should be exercised when interpreting the accuracy of the tradeware dates, as they are consistently earlier than radiocarbon dates from the same level, by 57 to 178 years. The reason for this is argued to be careful handling and curation of the exotic wares, giving them a long use life before their final deposition as broken sherds at Macapainara (Fenner and Bulbeck 2013). Certainly, the tradeware identifications would be inconsistent with occupation at Macapainara any earlier than the sixteenth century, and indeed would be consistent with a seventeenth-century onset of habitation. It should be noted that most of the sherds were small, with a median weight of $0.82 \mathrm{~g}$ and a range of $0.15-22.73 \mathrm{~g}$. While the small size of the available sherds may cast doubt on some of the individual identifications, especially those that lack diagnostic decorations, together the identifications point to a coherent assemblage dated to the quite short time frame of the sixteenth to nineteenth centuries $\mathrm{AD}$.

\section{Stone artefacts}

The excavation at Macapainara recovered 392 stone artefacts distributed over the three excavation squares (Table 2.3), including flakes, flake fragments, retouched flakes, cores and a hammer stone. The majority of artefacts occur in the upper half of the sequence in all squares and their distribution follows that of other materials associated with occupation at the site (Figure 2.10). The raw material is dominated by red and cream cherts ( 89.5 per cent) and opaque brown chalcedonies (3.8 per cent), with a variably thin porous cortex (Table 2.4 ). These sources are locally available, where chert seams occur in the limestone and in secondary sources as cobbles within streams and river beds.

As noted, the quantity of stone artefacts is surprising in view of the historical context, so the variables used to establish each artefact as anthropogenic were recorded and summarised in Table 2.5. Results indicate a lower than expected frequency of these variables (see Hiscock 2007:10); however, all stone artefacts at Macapainara displayed a combination of these conchoidal variables (Table 2.5). 

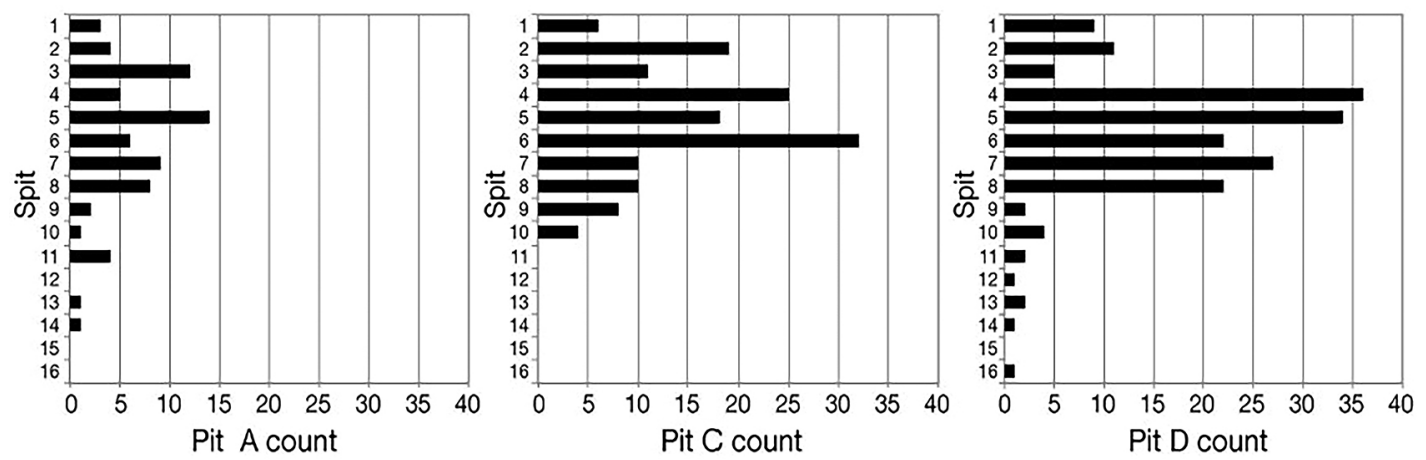

Figure 2.10. Vertical distribution of stone artefacts in each square relative to spit.

Source: Tim Maloney. Redrawn by CartoGIS ANU.

Table 2.3. Frequency of Macapainara stone artefacts across three excavation squares relative to spit.

\begin{tabular}{|l|r|r|r|}
\hline Spit & Square A & \multicolumn{1}{|c|}{ Square C } & \multicolumn{1}{|c|}{ Square D } \\
\hline 1 & 3 & 6 & 9 \\
\hline 2 & 4 & 19 & 11 \\
\hline 3 & 12 & 11 & 5 \\
\hline 4 & 5 & 25 & 36 \\
\hline 5 & 14 & 18 & 34 \\
\hline 6 & 6 & 32 & 22 \\
\hline 7 & 9 & 10 & 27 \\
\hline 8 & 8 & 10 & 22 \\
\hline 9 & 2 & 8 & 2 \\
\hline 10 & 1 & 4 & 4 \\
\hline 11 & 4 & - & 2 \\
\hline 12 & - & - & 1 \\
\hline 13 & 1 & - & 2 \\
\hline 14 & 1 & - & 1 \\
\hline 15 & - & - & - \\
\hline 16 & - & - & 1 \\
\hline Total & 70 & 143 & 179 \\
\hline
\end{tabular}

Source: Authors' summary.
Table 2.4. Macapainara raw material frequency.

\begin{tabular}{|l|r|r|}
\hline Raw material & Frequency \# & \% \\
\hline Chert & 351 & 89.5 \\
\hline Chalcedony & 15 & 3.8 \\
\hline Limestone & 8 & 2.0 \\
\hline Glass & 2 & 0.5 \\
\hline Quartz & 1 & 0.3 \\
\hline Quartzite & 1 & 0.3 \\
\hline Fine-grained sedimentary & 11 & 2.8 \\
\hline Mudstone & 3 & 0.8 \\
\hline Total & 392 & 100 \\
\hline
\end{tabular}

Source: Authors' summary.

Table 2.5. Macapainara frequency of conchoidal fracture variables.

\begin{tabular}{|l|c|c|c|c|c|}
\hline Variable & Negative scars & $\begin{array}{c}\text { External } \\
\text { initiation }\end{array}$ & Termination & Platform present & $\begin{array}{c}\text { Bulb of } \\
\text { percussion }\end{array}$ \\
\hline Frequency & 349 & 346 & 317 & 262 & 238 \\
\hline Assemblage \% & 88.8 & 88.1 & 80.7 & 66.7 & 60.6 \\
\hline
\end{tabular}

Source: Authors' summary.

The reduction sequences suggest onsite reduction and discard, rather than recycling of artefacts from older deposits predating the use of the hilltop as a fortified settlement. Cores, for example $(\mathrm{N}=27)$, were identified with zero to four rotations, between two and 12 flake scars, and varied amounts of cortex. The distribution of cortex on flake dorsal surfaces also suggests onsite flake production. For example, primary flakes as well as a range of secondary flakes with cortex along either the entire lateral margin, or the proximal and distal portions, indicates that pebbles and sub-angular nodules were reduced at the site (e.g. Marwick 2008). 
Of the 108 retouched flakes, few specimens exhibited invasive flaking (4.8 per cent) and none resembled reported formal tools from other Timor-Leste sites (e.g. Glover 1986; Marwick et al. 2016). Instead, retouch was predominately delivered onto the dorsal surface and restricted to medial and distal margins, where concentrations of step terminating or cascading scars accumulated on the majority of retouched flakes (73.6 per cent). These concentrations of step terminating scars are associated with low levels of flake reduction (AGIUR $=0.35$ ), yet the increasing frequency of step terminating retouch scars is associated with increasing AGIUR values $(\mathrm{t}=11.457, \mathrm{df}=40, \mathrm{p}=<0.0005)$. This trend suggests that the accumulation of retouch was not a strategy to remove the build-up of step terminating scars or steep retouched edge angles, as might be expected in the maintenance of cutting or scraping tools.

This unusual modification resembles existing descriptions of strike-a-light tools, where siliceous stone flakes were marginally retouched with metal implements to purpose sparks for fire lighting (Brumm 2006; Glover 1986:202; Glover and Ellen 1975:52-53; Pannell and O'Connor 2005:201; Scheans et al. 1970:180; Skertchly 1890:450, 451). From these studies, we can expect marginal concentrations of step fractures, crushing or cascading, bifacial battering, dense striations and typically minimal retouch before discard to be a reasonable indicator of strike-a-light functions (Andrefsky 2009:196; Brumm 2006:169-170; Glover and Ellen 1977; Staperd and Johansen 1999:768). Results demonstrate that such characteristic variables occur on the majority of flakes in the assemblage (Table 2.6). Figure 2.11 illustrates two examples of step terminating scar concentrations and striations, typical of chert retouched flake margins from Macapainara.

Table 2.6. Macapainara summary of characteristic edge modification variables.

\begin{tabular}{|l|c|c|c|}
\hline Variable & Observed & Not observed & \% Flakes \\
\hline Step terminating concentrations & 168 & 60 & 73.6 \\
\hline Parallel and non-parallel striations & 65 & 163 & 28.5 \\
\hline Bifacial battering & 124 & 104 & 54.8 \\
\hline Crushing & 118 & 110 & 51.75 \\
\hline
\end{tabular}

Source: Authors' summary.

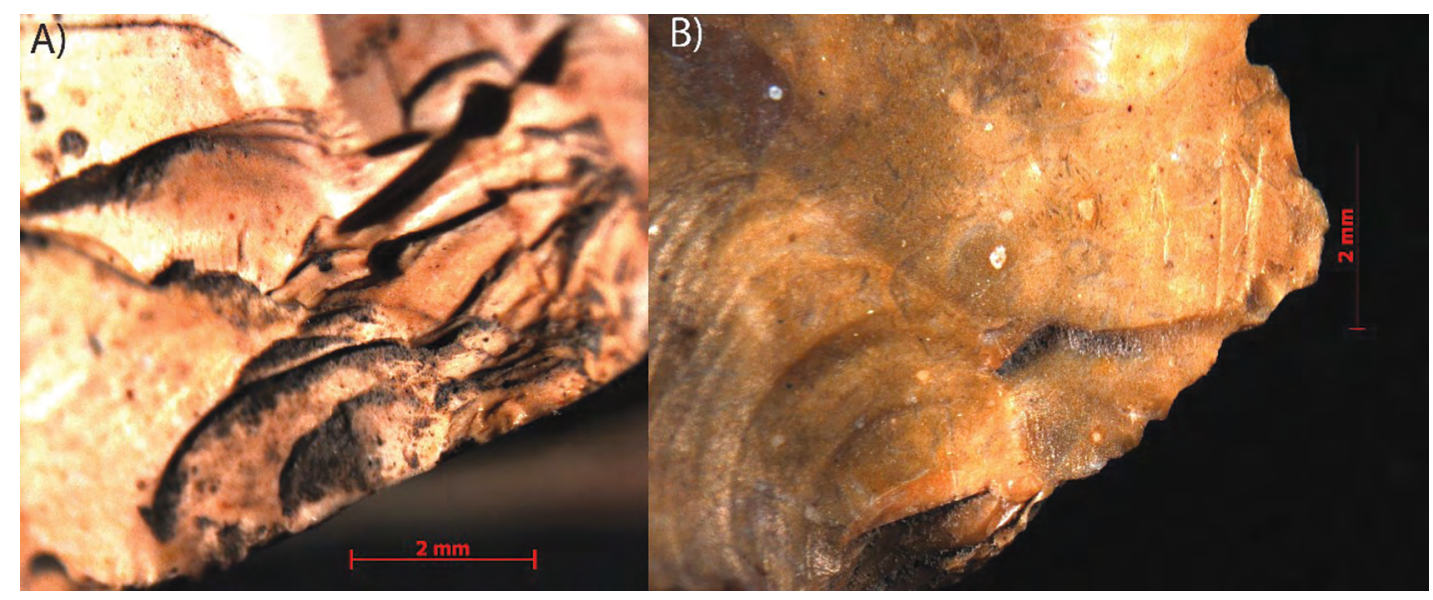

Figure 2.11. Margins of typical chert retouched flakes, thought to be strike-a-light tools.

A: Step terminating scar concentration; B: Parallel striations emerging from marginal scars.

Source: Photos courtesy of Tim Maloney.

In summary, the Macapainara lithic assemblage indicates that cores were reduced at the settlement to produce small, thick and squat-shaped flakes suitable for use as strike-a-lights.

\section{terra australis 53}




\section{Vertebrate faunal remains}

Most of the vertebrate faunal remains from Macapainara were recovered from D Square, with much of it only slightly weathered (Figure 2.12). A total of 239 fragments of bone were identified to taxon, with mammals accounting for 65.27 per cent $(\mathrm{N}=156)$ of all identified vertebrate remains, with smaller amounts of fish $(\mathrm{N}=73,30.54$ per cent), reptile $(\mathrm{N}=8,3.34$ per cent) and bird ( $\mathrm{N}=1,0.4$ per cent) (Table 2.7).

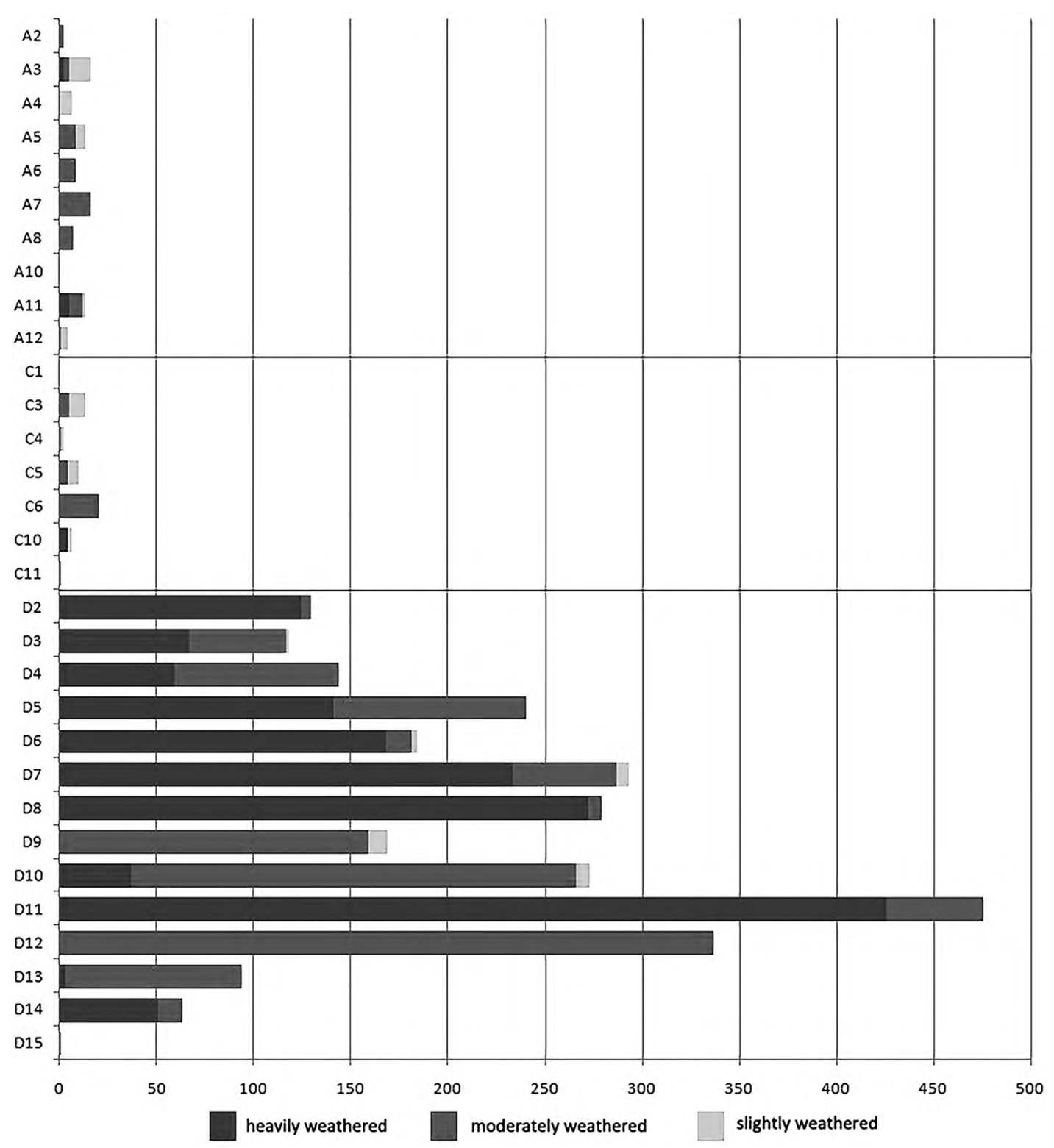

Figure 2.12. Distribution of Macapainara vertebrate faunal remains, and associated weathering (NISP).

Source: Noel Amano Jr and Philip Piper. Redrawn by CartoGIS ANU.

Sixty-three fragments of Bovinae were recorded from all depths within Square D as deep as Spit 14. Of these, three were identified as belonging to cattle Bos sp. and no specimens of the water buffalo Bubalus bubalis were recorded. Numerous long bone fragments classified as 'large mammal' are probably also Bovinae, especially below Square D Spit 6 where this is the only large mammal identified in the zooarchaeological record. Fragments of most high meat-yielding body parts such as the humerus, scapula and pelvis, and those of lower utility like the phalanges, 
are all represented, suggesting that whole carcasses were being dressed at the site. Very few skeletal elements of Bovinae useful for ageing were recovered from Macapainara. A moderately worn (Grant Stage F) lower left M1 from Square D Spit 11 and an upper left Bos sp. dp4 from D Spit 10 were probably from a young adult, and a fragmented, heavily worn upper right M3 fragment (middle tooth column) is probably from an individual greater than four years of age (Grigson 1982).

Table 2.7. Macapainara NISP recorded by square and spit for the three trenches that produced vertebrate remains during the 2008 excavations.

\begin{tabular}{|l|c|c|c|c|c|c|c|c|c|c|c|}
\hline & \multicolumn{9}{|c|}{ Taxon } \\
\hline $\begin{array}{l}\text { Square/ } \\
\text { layer }\end{array}$ & Teleosteii & Serpentes & Gekkonidae & Aves & Phalanger o. & Rodentia & $\begin{array}{c}\text { Canis } \\
\text { f. }\end{array}$ & $\begin{array}{c}\text { Equus } \\
\text { f.c. }\end{array}$ & Sus s. & Bovinae & Capra $h$. \\
\hline A2 & - & - & - & - & - & - & - & - & - & - & - \\
\hline A5 & - & - & - & - & - & - & - & - & - & - & - \\
\hline A7 & - & - & - & - & - & - & - & - & - & - & - \\
\hline C3 & - & - & 1 & - & - & - & - & - & - & - & - \\
\hline C4 & - & - & - & - & - & - & - & - & - & - & - \\
\hline C6 & - & - & - & - & - & - & - & - & - & - & - \\
\hline D2 & - & - & - & - & - & - & 2 & - & 5 & 1 & - \\
\hline D3 & 2 & - & - & - & - & - & - & - & 2 & 1 & 1 \\
\hline D4 & 2 & - & - & - & - & 1 & 1 & 1 & 3 & 1 & - \\
\hline D5 & 6 & - & - & - & - & - & 4 & 1 & 22 & 2 & - \\
\hline D6 & 5 & - & - & - & - & - & 2 & - & 11 & 4 & 1 \\
\hline D7 & 23 & - & - & - & - & - & 1 & - & 3 & 13 & - \\
\hline D8 & 14 & - & - & - & 1 & - & 3 & - & 3 & 8 & - \\
\hline D9 & 6 & 4 & - & - & - & - & - & - & 2 & 8 & - \\
\hline D10 & 4 & 3 & - & - & - & - & 1 & - & 7 & 3 & - \\
\hline D11 & - & - & - & 1 & - & - & - & - & 6 & 16 & - \\
\hline D12 & - & - & - & - & - & - & - & - & 1 & 4 & - \\
\hline D13 & - & - & - & - & - & - & - & - & 1 & 1 & 4 \\
\hline D14 & 7 & - & - & - & - & - & - & - & - & 1 & 3 \\
\hline D15 & - & - & - & - & - & - & - & - & - & - & - \\
\hline
\end{tabular}

"D4 = 1 Siluriformes; D5 = 1 Elasmobranch; D6 = 2 Diodontidae; D7 = 1 Lutjanidae, 1 Serranidae, 1 Scaridae, 6 Diodontidae; D8 = 3 Diodontidae; D9 = 1 Serranidae.

Square A produced no faunal remains that could be identified to family or lowest taxonomic level.

Phalanger o. = Phalanger orientalis; Equus f.c. = Equus ferus caballus; Sus s. = Sus scrofa; Capra h. = Capra hircus;

Canis $f$. = Canis familiaris.

Source: Authors' summary.

Stages of epiphysial fusion suggest Bovinae of a variety of ages are represented in the assemblage. Two metapodial fragments with fused distal ends recovered from Square D Spit 6 represent individuals more than two to three years old (Silver 1970; Schmid 1972). An unfused distal tibia from Square D Spit 10 is from an individual less than two years old and an unfused acetabulum recovered from Square D Spit 9 suggests a juvenile individual less than six months old. A left tibia with fused proximal epiphysis from Square D Spit 11 represents the oldest bovine in the assemblage and is from an individual that is more 42 months old.

Pig bone was as common in the assemblage (NISP $=66,27.6$ per cent of identified elements) as fragments of Bovinae and was also recovered from all depths in Square D. The majority of the pig elements identified were tooth fragments $(\mathrm{N}=52)$, albeit with only six complete teeth recorded. Based on canine morphology, both male and female individuals are represented in the 
assemblage. A loose unerupted lower right M1 from Square D Spit 2 and an unworn dp3 from Square D Spit 11 represent an individual not older than four to eight months. An unworn upper right M2 from Square D Spit 5 and an unworn upper central incisor from Square D Spit 2 are probably also from subadult individuals. Two complete isolated dp4s with roots (Grant Stage B and J respectively), demonstrating that they were not naturally shed, from Square D Spits 6 and 11 were from individuals of less than 12-18 months (Bull and Payne 1982). Notably no M3s were recorded in the assemblage, suggesting that most of the pigs were of young age when they were slaughtered.

Nine fragments of caprine bone were recorded in the Macapainara assemblage. Only the domestic goat Capra hircus has been introduced to Timor-Leste and all remains positively identified to CapralOvis are taken to be goat. Sheep are known to have been introduced to the region only in the very recent past. All but a single subterminal phalange from Square D Spit 3 were fragments of tooth. It is notable that the majority of the goat remains $(N=7)$ were recorded in the deeper spits of Square D Spits 13 and 14. Only two fragments were found higher in the sequence, a moderately worn upper right M2 recorded from Square D Spit 6 and a fused subterminal phalanx from Square D Spit 3. At least two individuals could be identified based on eight complete teeth recovered. A lower right P2 worn almost to the pulp cavity was recovered from Square D Spit 14, a moderately worn upper left M1 (Grant Stage E) and a lower left M1 (Grant Stage D) from Square D Spit 13 were all probably from adult individuals (Table 8 in Piper and Amano 2011). The four measurable teeth from Macapainara fall within the size range of a selection of goat molars held at the University of the Philippines Archaeological Studies Program (UP-ASP).

A total of 14 dog elements from at least two individuals were identified. Of the 10 dog teeth recovered, only three specimens could be measured due to the fragmentary nature of the other elements. A partially damaged lower left M1 from Square D Spit 6 measured $18.52 \mathrm{~mm}$ in length and $14.67 \mathrm{~mm}$ in breadth. This element is comparable in size to the M1s of the Southeast Asian dog specimens maintained at UP-ASP (average $\mathrm{L}=18.83 \mathrm{~mm}$, average $\mathrm{W}=14.03 \mathrm{~mm}$ ). A dog distal humeral shaft from Square D Spit 2 had a medio-lateral width of $22.78 \mathrm{~mm}$ and an antero-posterior depth of $15.15 \mathrm{~mm}$, which is relatively small in comparison to a dataset held in the UP-ASP zooarchaeological laboratory of 43 individuals (average M-L $=29.83 \mathrm{~mm}$, average A-P $=22.16 \mathrm{~mm}$ ). A moderately worn lower right M2 from Square D Spit 6 (Figure 12 in Piper and Amano 2011) had a length of $12.15 \mathrm{~mm}$ and maximum breadth of $11.51 \mathrm{~mm}$. This M2 is significantly larger than those maintained in the UP-ASP reference collection (average $\mathrm{L}=9.59 \mathrm{~mm}$, average $\mathrm{B}=11.23 \mathrm{~mm}$ ). No butchery was recorded on the dog bones.

Two horse bones were recorded in the assemblage. A heavily weathered basal phalanx from Square D Spit 5 exhibited the pathological modification non-articular periostosis. Non-articular periostosis is not uncommon in modern horses and has even been recorded in Equus conversidens from the Pleistocene (Scott and Rooney 2001). It is characterised by lesions related to the avulsion of ligaments from their bony attachments resulting normally from irregular and jerky movements of the affected leg segment (Rooney and Robertson 1996). Such instability usually results from misplacement of the foot on the surface (Scott and Rooney 2001). This appears to have been exacerbated in this specimen from Macapainara because the basal phalange itself is malformed, with one distal condyle missing its medial or lateral margins making the bone asymmetrical. A fragmented distal articular end of a horse metacarpal was also recorded in Square D Spit 4.

Nine fragments of terrestrial wild vertebrates were identified at Macapainara. Snake vertebrae $(\mathrm{N}=7)$ were recovered from Square D Spit 9 and Square D Spit 10, a gecko vertebra in Square C Spit 3 and two phalanges tentatively identified as from the northern common cuscus (Phalanger orientalis) from Square D Spit 7 and Square D Spit 8. The only rodent bone, the proximal end 
of an ulna from D4, has a similar size and morphology to that expected for a commensal species. A fragment of the right tarsometatarsus from a chicken-sized bird was identified from Square D Spit 11 but it lacks the diagnostic spur that develops in Gallus gallus.

Of the 73 fragments of fish recorded in the assemblage, 17 could be identified to subclass or family. The majority of the bones were either undiagnostic vertebrae or spines. Fish remains were recorded at all depths. A serrated pectoral spine, probably from a catfish (order Siluriformes) was recovered from Square D Spit 4 (Figure 15c in Piper and Amano 2011). The distinctive, robust dermal spines of pufferfish (Diodontidae) were identified $(\mathrm{N}=11)$ in Square D Spits 7 and 8 (Figure 15d in Piper and Amano 2011), and the anterior portions of grouper (Serranidae) and snapper (Lutjanidae) dentary bones were found in Square D Spit 7, as well as a pharyngeal plate of a parrotfish (Scaridae) (Figure 15b in Piper and Amano 2011). An anterior fragment of a grouper left maxilla was recorded in Square D Spit 14 and a shark or ray (elasmobranch) vertebra was recovered from Square D Spit 5.

\section{Invertebrate faunal remains}

Square A contained $16.3 \mathrm{~kg}$ of shell comprised of 65 taxa (Figure 2.13), 38 of which were identified to species, 18 to genus and 10 to family or greater. The dominant species throughout time, based on MNI counts, were, in descending order; Turbo bruneus, Angaria delphinus, Tectus fenestratus, Trochus maculatus, Rochia nilotica, Nassarius arcularia, Nerita plicata, Nerita albicilla, Lambis sp., and Vasum turbinellum. The dominant family groups through time, based on MNI counts, were, in descending order: Turbinidae, Tegulidae, Trochidae, Neritidae, Strombidae, Haliotidae, Conidae, Nassariidae and Angariidae. Square A also returned $88.3 \mathrm{~g}$ of sea urchin, from Spits 2-13.

Square C contained $19.9 \mathrm{~kg}$ of shell (Figure 2.13). A total of 79 taxa were identified for Square C, 52 of which were identified to species, 17 to genus and 11 to family or greater. The dominant species throughout time, based on MNI counts, were, in descending order: Turbo bruneus, Turbo chrysostomus, Tectus fenestratus, Trochus maculatus, Rochia nilotica, Angaria delphinus, Nassarius arcularia, Nerita albicilla, Cymbiola vespertilio, and Haliotis sp. The dominant family groups through time, based on MNI counts, were, in descending order: Turbinidae, Trochidae, Tegulidae, Neritidae, Strombidae, Haliotidae, Conidae, Nassaridae and Angariidae.

Square D contained $26.0 \mathrm{~kg}$ of shell (Figure 2.13). A total of 74 taxa were identified for Square D, 48 of which were identified to species, 18 to genus, and 9 to family or greater (see Appendix Table 2.A2). The dominant species throughout, based on MNI counts, were, in descending order: Turbo bruneus, Tectus fenestratus, Trochus maculatus, Turbo chrysostomus, Rochia nilotica, Angaria delphinus, Nassarius arcularia, Nerita albicilla, Nerita plicata and Haliotis sp. The dominant family groups through time, based on MNI counts, were, in descending order: Turbinidae, Tegulidae, Trochidae, Neritidae, Haliotidae, Nassariidae, Angariidae, Conidae and Strombidae.

Several of the Turbo, Tectus and Angaria shells exhibited a single hole flaked into their body whorl, along with a minimal amount of chipping localised around the aperture (see examples in Figure $2.14 \mathrm{C}-\mathrm{D})$. On most of these shells, no further signs of modification were observed, and thus it seems that this treatment of the shells was most probably for food processing. 

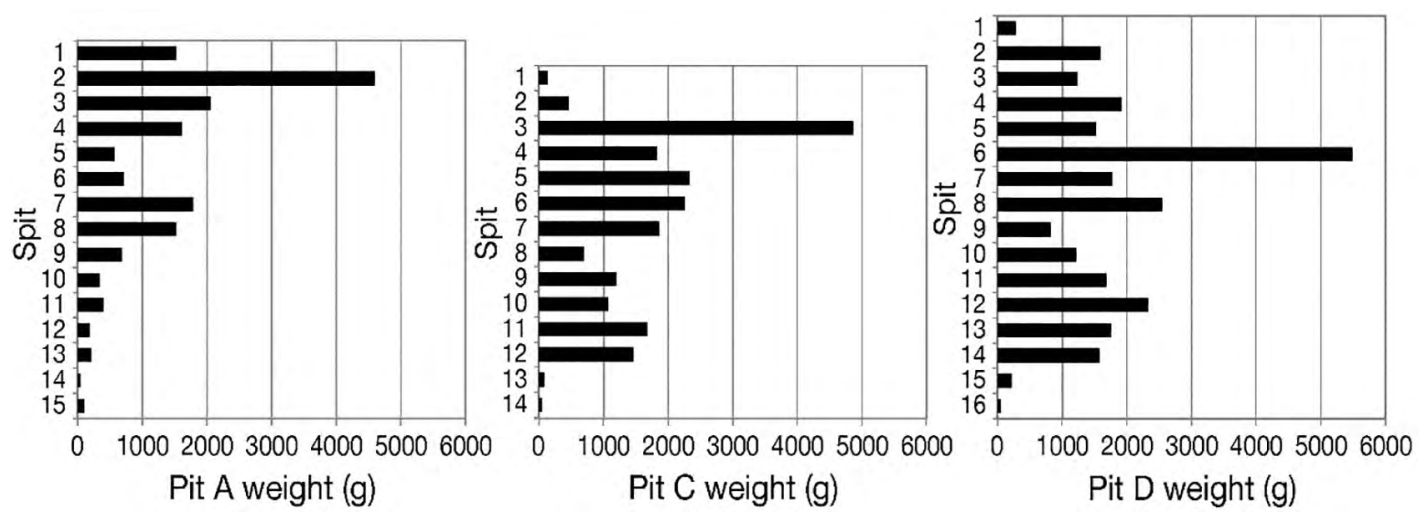

Figure 2.13. Total shell weight from Macapainara Squares A, C and D (g).

Source: Mirani Litster.

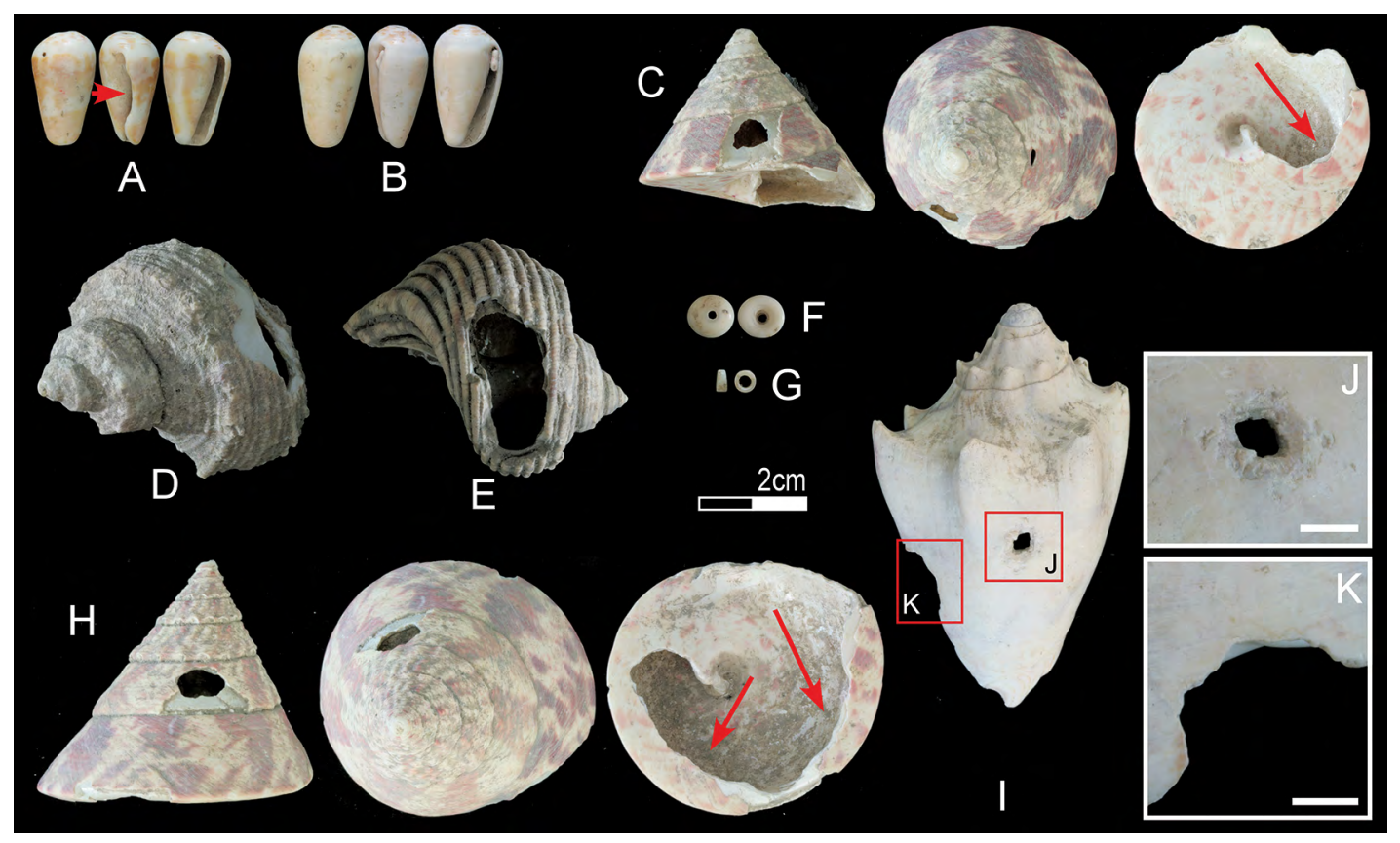

Figure 2.14. Worked and utilised sea shells from Macapainara.

$\mathrm{A}$ and $\mathrm{B}$ : Juvenile cone snails used as beads, red arrow indicates worn lip from stringing; $\mathrm{C}$ and $\mathrm{H}$ : Rochia nilotica shells with single perforation in spire and worked base (indicated by red arrows); D and E: Turbo shells with single perforation; F: Conomurex shell apex exhibiting extreme rounding as polish from use; G: Scaphopod bead; I-K: Cymbiola vespetilio shell with perforation and notched lip. Scale bars $=5 \mathrm{~mm}$.

Source: Photos courtesy of Michelle Langley.

\section{Mollusc habitat}

With the exception of the few individuals of Melanoides tuberculata, all of the Macapainara molluscs identified to species level are reef, rocky shore, or sand and sea grass associated taxa. The north coast of Timor-Leste is comprised of the Baucau Limestone formation: a series of terraces that alternate between in situ coral reef and calcarenite, demarcating the stages of Timor's uplift from the Pleistocene onwards (Audley-Charles 1968). The limestone reef fringes the coastline and the fore reef plunges abruptly to the continental shelf. The intertidal reef flat is littered with dead corals and other rubble, with small patches of sand and sea grasses. The near absence of bivalves in the Macapainara mollusc assemblage reflects the relative paucity of bivalves in 
the molluscan fauna of Timor-Leste due to the lack of depositing shores. There is a distinct paucity of mangroves along the north coast of Timor-Leste, and the few forests that do exist are small in size and sparse (Alongi 2009:537). No mangrove habitats occur today within a $10 \mathrm{~km}$ radius of Macapainara. The absence of mangrove-associated taxa in the Macapainara assemblage is therefore not surprising.

Five complete $M$. tuberculata shells were recovered from the Macapainara excavation (two from Square A, both Spit 15; two from Square C, one from Spit 8, the other from Spit 11; one from Square D Spit 10). M. tuberculata is a freshwater gastropod that can tolerate brackish conditions. It is predominantly a burrowing species and mainly feeds on algae. The individuals range from 0.1 to $0.2 \mathrm{~g}$ in mass, and from 0.9 to $2.1 \mathrm{~cm}$ in shell length (from apex to columella base). Given the small number of $M$. tuberculata, their small size and the lack of other freshwater shells in the assemblage, it seems likely that they entered the site as an incidental by-product of another activity, such as water collection, or plant gathering.

Several of the marine molluscs also occur in very low numbers and individual shells are of small size. These may have been brought ashore incidentally attached to pieces of substrate or other shells. For example, Nassarius pauper is a common predator of corals, and if live corals or other resources were collected from the reef these taxa may have been collected incidentally. Drupella cornus and Mipus sp. also fall into this category.

Since habitat preference, or tolerance, can differ markedly within Molluscan families, genera and occasionally species, given the different levels of identification for the Macapainara assemblage it is impossible to ascribe precise habitat ranges to all taxa, especially fragments identified only to family or genus level.

In summary, the majority of the Macapainara shell assemblage was collected for consumption, and from the rock and reef platform directly to the north of the site. Based on MNI, Turbo bruneus is the dominant species across all three squares and through time, while Turbinidae, Tegulidae, Trochidae, Angariidae and Neritidae are the dominant family groups. Turbo bruneus is a large gastropod that is a popular item of contemporary local cuisine. Trochidae, Tegulidae and even small Nerita sp. are also still collected for consumption. Focus seems to have been on the larger species from the families Turbinidae and Trochidae, although even relatively small Nerite species were regularly collected. Nerites are available at the upper reaches of the intertidal zone so are available for collection even at high tide.

\section{Organic artefacts}

\section{Shell}

Anthropogenic traces reflect both the alteration of shells to access the animal inside (as outlined above), as well as more extensive working to create ornamental and utilitarian technologies.

Evidence for the selection of Turbo, Rochia and Tectus shells, possibly for making fishhooks, beads or similar small items, is found in extensively flaked whorls (Figure 2.15 A-D). Examples from Square C Spit 8 and Square D Spit 6 show sectioning via indirect percussion was also used to reduce the shell (Figure $2.15 \mathrm{~B}-\mathrm{C}$ ). The remnants of an extremely large and heavily worked Turbo (Figure $2.15 \mathrm{~A}$ ) similarly indicates that this genus was targeted for tool manufacture, as was Nautilus pompilius. For this latter species, several siphuncle pieces displaying anthropogenic flaking up to their edges, as well as some $35 \mathrm{~g}$ of outer shell fragments, were identified, though no preforms, finished tools or ornaments of any of these raw materials were found. 


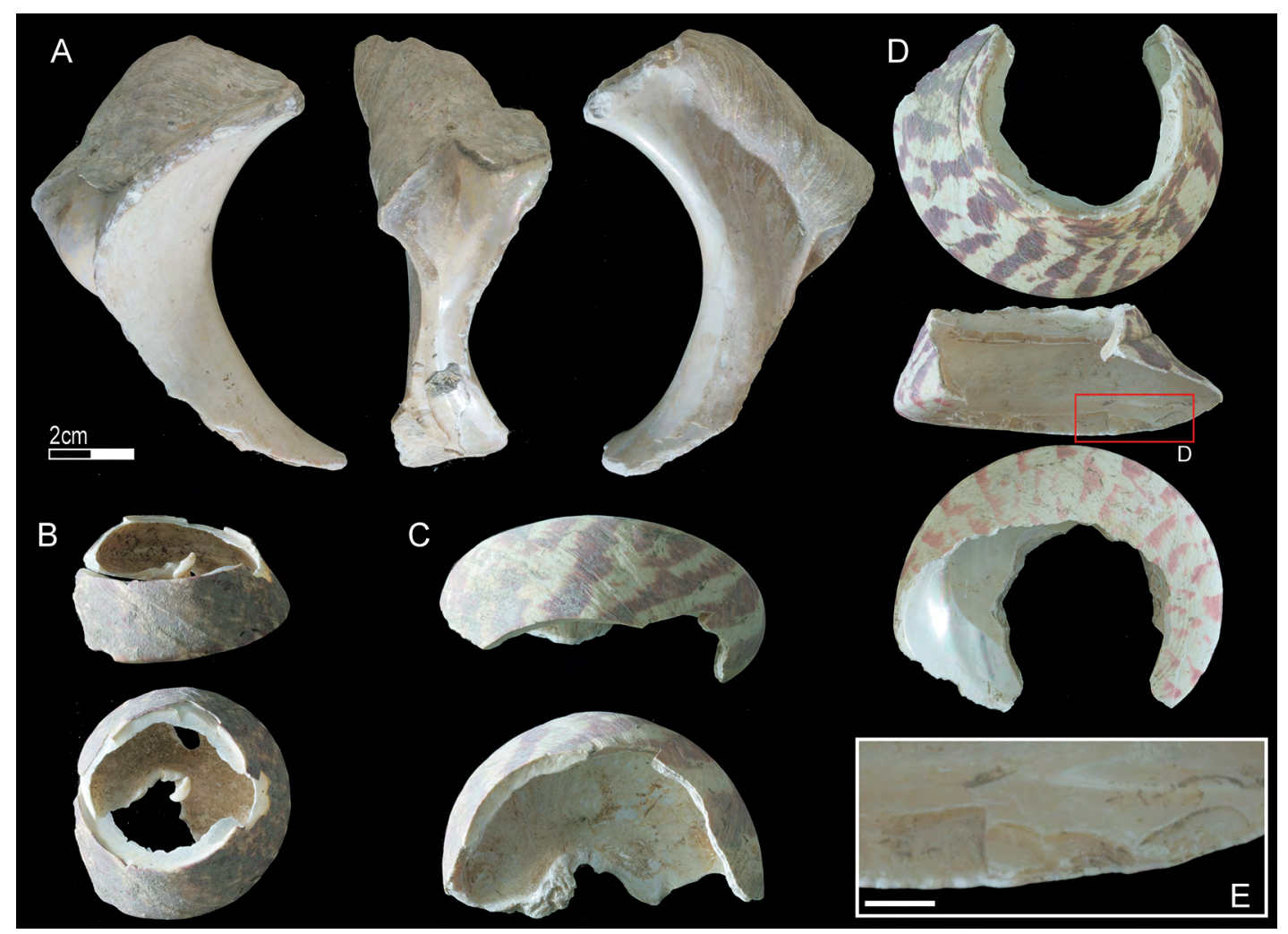

Figure 2.15. Worked Rochia, Tectus and Turbo shells.

A: Remnant of large and extensively worked Turbo shell; B: Tectus pyramis shell exhibiting sawn sections; C: Rochia nilotica shell exhibiting sawn sections; D and E: Body of a Rochia nilotica shell with anterior and posterior sections reduced by consecutive flaking. Scale bar $=5 \mathrm{~mm}$.

Source: Photos courtesy of Michelle Langley.

Another gastropod, a Cymbiola vespetilio (Figure 2.14 I), exhibits numerous impact marks (localised pitting) around a single small puncture (Figure $2.14 \mathrm{~J}$ ). These marks indicate that a sharp point was repeatedly struck against its surface in order to pierce the shell body. A notch is also found in the outer lip (Figure $2.14 \mathrm{~K}$ ), suggesting that the shell suffered repeated stress to this localised area. This combination of perforation and notch implies that it was strung in some manner, perhaps being used as a weight or ornament.

Also found (Square A Spit 4) were three Conomurex lubuanus tops, their bodies flaked away and a hole driven through their centre to create a kind of large bead (Figure 2.16 A-C). Comparison of these artefacts with ethnographic material finds that they are likely spindle whorls-identical specimens continue to be used in the region today. Comparison of the Macapainara Conomurex with the ethnographic example shown in Figure 2.16 found that, while the former had their body removed roughly via percussion and the latter was finished off to a smooth and horizontal plane by grinding, all are of similar size and weight, and their central perforations exhibit similar characteristics such as size, edge rounding and cross-section. Interestingly, another three Conomurex were found one spit above, and are of similar size. Two of these examples have begun to be reduced with targeted direct flaking into their lip. 

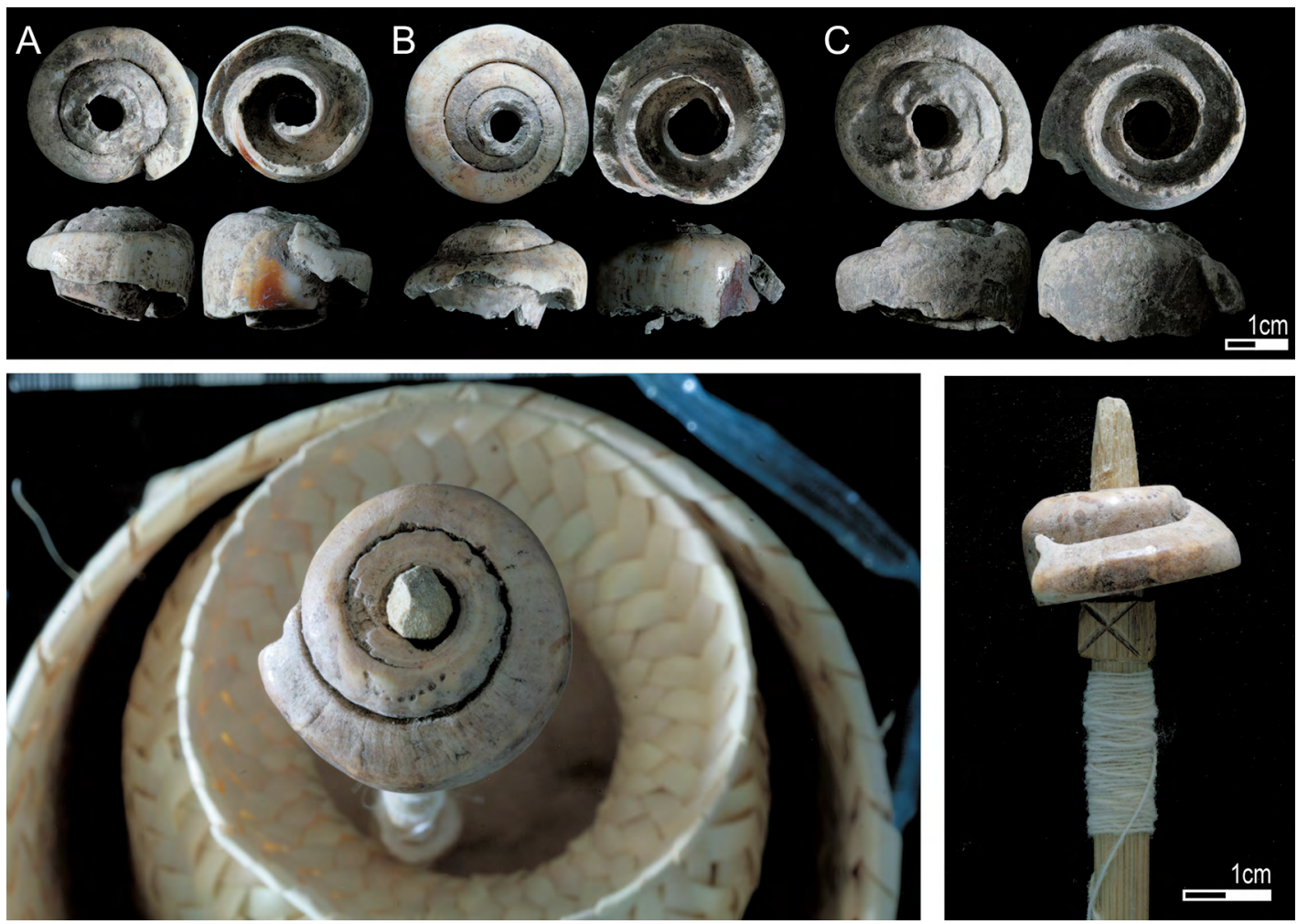

Figure 2.16. Conomurex luhuanus shell spindle whorls.

A-C: Spindle whorls recovered from Macapainara; Bottom left and right: Ethnographically collected Conomurex luhuanus spindle whorl from Timor-Leste. Used to spin cotton.

Source: Photos courtesy of Michelle Langley.

Finally, four shells appear to be items of personal ornamentation. Two are juvenile strombids (Figure 2.14 A and B), the hole in their posterior extremity the result of natural beach-wash abrasion, though one exhibits significant wear from being strung on its outer lip (Langley and O'Connor 2016). A third, also made on a Conomurex, though this time only its top, shows significant rounding and polish accrued through wear (Figure 2.14 F) (Langley and O'Connor 2015). Finally, a short length of scaphopod was identified (Figure $2.14 \mathrm{G}$ ). Ethnographic observations of the working of these shells for beads from northwestern Australia found that creating sections requires a sharp and directed tap with a hard object (such as a knife), and thus, its form may be deliberately determined (Balme et al. 2018).

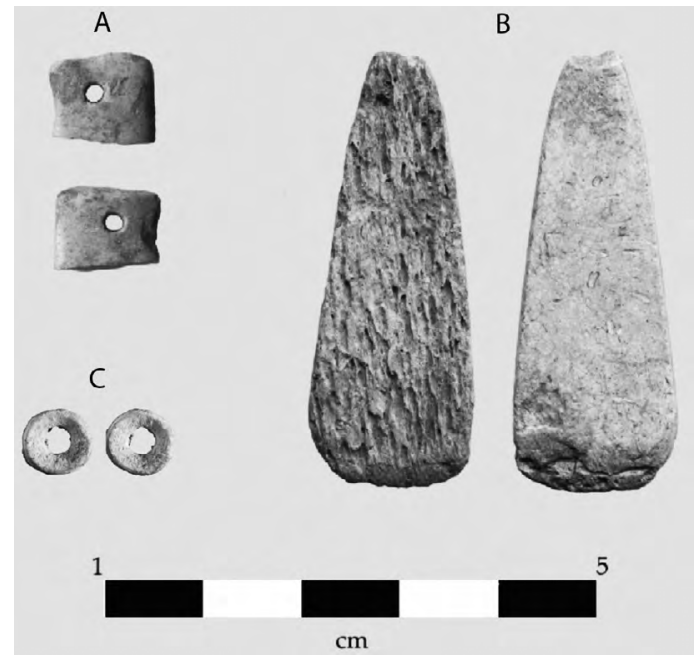

Figure 2.17. Bone artefacts.

A: Polished tooth ornament recovered from D4; B: Spatulashaped bone tool from D5; C: Drilled fish vertebrae.

Source: Photos A-B courtesy of Noel Amano Jr; Photo C courtesy of Michelle Langley. 
Bone

An ornament made of tooth was recovered from Square D Spit 4 (Figure 2.17 A). It is heavily polished and ground on three sides and has a $1.91 \mathrm{~mm}$ circular hole $4 \mathrm{~mm}$ from the intact edge. It has a maximum length of $10.95 \mathrm{~mm}$ and a maximum depth of $2.56 \mathrm{~mm}$. The hole appears to be worn, suggesting that the ornament was strung.

A spatula-shaped bone tool was recovered from Square D Spit 5 (Figure 2.17 B). It measured $45.75 \mathrm{~mm}$ in length, with a maximum width of $17.17 \mathrm{~mm}$ and a thickness of $3.54 \mathrm{~mm}$. The tool was flat with a cortical bone surface evident on one side and medullary on the other. The wide end was ground in a sloping manner from the cortical surface to make a sharp rounded edge. There was no real attempt to give the tool a high polish, although both sides have been ground. The wider end is rough and pitted from use.

\section{Conclusions}

Our survey and excavation results from Macapainara indicate that the fortified structure was occupied for domestic living and was also the site of ritual and symbolic activities. Oral accounts of the ethnohistories of the area indicate that a significant population formerly lived within the settlement. Certainly, the diversity and quantity of earthenware and tradeware suggests cooking and consumption of food and the storage of perishables and water. Stone strike-a-lights were made onsite, presumably as fire starters and remained an essential component of Fataluku travelling kit until well into the twentieth century. The presence of a number of shell spindle whorls indicates fibre production and probably also weaving took place within this domestic space.

The settlement served as a locus from which a variety of subsistence pursuits were carried out across a broad geographic area encompassing grazing lands, marine reefs and rock platforms and forest. All excavation areas contained abundant earthenware pottery, animal bones and a wide variety of marine shellfish. While some of the shellfish were clearly transported for reduction into decorative and utilitarian items, the larger proportion seems to have been for subsistence. Domestic species contributed most of the protein in the diet and comprise predominantly cattle and pigs; however, some wild animals such as cuscus were hunted and fish were brought back from the coast, albeit in small numbers. Horse was also present, and these were important commodities during the sixteenth to eighteenth centuries AD in Timor (Gunn 2010).

Based on current evidence from the radiocarbon dates, Macapainara was occupied during the seventeenth to nineteenth centuries $\mathrm{AD}$. Most of the glass, glass beads and tradewares can also be dated to this period, although the tradewares would also allow for initial occupation as early as the sixteenth century. The sixteenth to nineteenth centuries coincide with the advent and expansion of European colonial activities in the region, and mesh well with local ratu oral history which recounts the occupation at Macapainara as a time when local raiding was rife and they were engaged in slaving and the sandalwood trade.

\section{References}

Alongi, D.M. 2009. Paradigm shifts in mangrove biology. In G. Perillo, E. Wolanski, D. Cahoon and M. Brinson (eds), Coastal wetlands: An integrated ecosystem approach, pp. 615-640. Elsevier, Amsterdam.

Andrefsky, W. Jr 2009. Lithics: Macroscopic approaches to analysis. Cambridge Manuals in Archaeology. 2nd edition. Cambridge University Press, New York. 
Audley-Charles, M. 1968. The geology of Portuguese Timor. Burlington House, London.

Balme, J., S. O'Connor and M.C. Langley 2018. Marine shell ornaments in north western Australian archaeological sites: Different meanings over time and space. In M.C. Langley, M. Litster, D. Wright and S. May (eds), The archaeology of portable art: Southeast Asia, Pacific, and Australian perspectives, pp. 258-273. Routledge, London. doi.org/10.4324/9781315299112-16.

Bar-Yosef Mayer, D.E. 2005. The exploitation of shells as beads in the Palaeolithic and Neolithic of the Levant. Paléorient 31:176-185. doi.org/10.3406/paleo.2005.4796.

Branyan, L., N. French and J. Sandon. 1989. Worcester Blue and White porcelain 1751-1790: An illustrated encyclopaedia of the patterns. Barrie and Jenkins, London.

Brown, R.M. 2004. The Ming gap and shipwreck ceramics in Southeast Asia. Unpublished PhD thesis, University of California, Los Angeles.

Brumm, A. 2006. Fire-making using a stone 'strike-a-light' in the Soa Basin of Flores, Indonesia. Bulletin of the Indo-Pacific Prehistory Association 26:168-170.

Buck, C., G. Boden, A. Christen and G. James 1999. BCal online radiocarbon analysis tool. bcal.shef. ac.uk. Accessed 10 September 2010. doi.org/10.11141/ia.7.1.

Bulbeck, D. 1996-97. The Bronze-Iron Age of South Sulawesi, Indonesia: Mortuary traditions, metallurgy and trade. In F.D. Bulbeck and N. Barnard (eds), Ancient Chinese and Southeast Asian Bronze Age cultures. Volume II, pp. 1007-1076. Southern Materials Center, Taipei.

Bulbeck, D. 2012. Tradeware and glass sherds, and beads and other ornaments excavated at Macapainara and Vasino, East Timor, in 2008. Unpublished report to the Department of Archaeology and Natural History, The Australian National University, Canberra. (Available from the author.)

Bulbeck, F.D. 1992. A tale of two kingdoms: The historical archaeology of Gowa and Tallok, South Sulawesi, Indonesia. Unpublished PhD thesis. The Australian National University, Canberra.

Bull, G. and S. Payne 1982. Tooth eruption and epiphysial fusion in pigs and wild boar. In B. Wilson, C. Grigson and S. Payne (eds), Ageing and sexing animal bones from archaeological sites, pp. 55-71. British Series 109. British Archaeological Reports, Oxford.

Classen, C. 1998. Shells. Cambridge University Press, Cambridge.

Cristiani, E., R. Farbstein and P. Miracle 2014. Ornamental traditions in the Eastern Adriatic: The Upper Palaeolithic and Mesolithic personal adornments from Vela Spila (Croatia). Journal of Anthropological Archaeology 36:21-31. doi.org/10.1016/j.jaa.2014.06.009.

d'Errico, F., P. Jardón-Giner and B. Soler-Mayor 1993. Critères à base expérimentale pour l'étude des perforations naturelles et intentionnelles sur coquillages. In P.C. Anderson (ed.), Traces et fonction: Les gestes retrouves—Actes du Colloque Internationale de Liège, pp. 243-254. Éditions Eraul, Liège.

Fenner, J.N. and D. Bulbeck 2013. Two clocks: A comparison of ceramic and radiocarbon dates at Macapainara, East Timor. Asian Perspectives 52(1):143-156. doi.org/10.1353/asi.2013.0005.

Francis, P. Jr 1999. Beads of the world: A collector's guide with revised price references. 2nd edition. Schiffer Publishing, Atglen, PA.

Frasché, D.F. 1976. Southeast Asian ceramics ninth through seventeenth centuries. The Asia Society, Washington D.C.

Glover, I. 1986. Archaeology in Eastern Timor, 1966-67. Terra Australis 11. Department of Prehistory, Research School of Pacific Studies, The Australian National University, Canberra. 
Glover, I.C. and R.F. Ellen 1975. Ethnographic and archaeological aspects of a flaked stone collection from Seram, eastern Indonesia. Asian Perspectives 18(1):51-60.

Glover, I.C. and R.F. Ellen 1977. A further note on flaked stone material from Seram, eastern Indonesia. Asian Perspectives 20(2):236-240.

Godden, G.A. 1974. British pottery: An illustrated guide. Barrie and Jenkins, London.

Goodman, T. 1998. The sosolot exchange network of Eastern Indonesia. In J. Miedema, C. Ode and R.A.C. Dam (eds), Perspectives on the bird's head of Irian Jaya: Proceedings of the conference, Leiden, 13-17 October 1997, pp. 421-454. Editions Rodopi B.V., Amsterdam.

Grant, A. 1982. The use of tooth wear as a guide to the age of domestic ungulates. In B. Wilson, C. Grigson and S. Payne (eds), Ageing and sexing animal bones from archaeological sites, pp. 91-108. British Series 109. British Archaeological Reports, Oxford.

Green, J., R. Harper and S. Prishanchittara 1981. The excavation at the Ko Kradat wrecksite, Thailand, 1979-1980. Western Australian Museum Department of Maritime Archaeology, Perth.

Grigson, C. 1982. Sex and age determination of some bones and teeth of domestic cattle: A review of the literature. In B. Wilson, C. Grigson and S. Payne (eds), Ageing and sexing animal bones from archaeological sites, pp. 7-23. British Series 109. British Archaeological Reports, Oxford.

Gunn, G.C. 2010. Historical dictionary of East Timor. Scarecrow Press, Lanham.

Guy, J.S. 1986. Oriental trade ceramics in South-East Asia: Ninth to sixteenth centuries. Oxford University Press, Oxford.

Harrisson, B. 1990. Pusaka: Heirloom jars of Borneo. Oxford University Press, Oxford.

Harrisson, B. 1995. Later ceramics in South-East Asia sixteenth to twentieth centuries. Oxford University Press, Oxford.

Hiscock, P. 2007. Artefacts on Aru: Evaluating the technological sequences. In S. O'Connor, M. Spriggs and P. Veth (eds), The archaeology of the Aru Islands, Eastern Indonesia, pp. 205-234. Terra Australis 22. ANU Press, Canberra. doi.org/10.22459/ta22.2007.10.

Kuhn, S. 1990. A geometric index of unifacial reduction for stone tools. Journal of Archaeological Science 17(5):585-593. doi.org/10.1016/0305-4403(90)90038-7.

Langley, M.C. and S. O’Connor 2015. 6,500-year-old Nassarius shell appliqués in Timor-Leste: Technological and use wear analyses. Journal of Archaeological Science 62:175-192. doi.org/10.1016 /j.jas.2015.06.012.

Langley, M.C. and S. O’Connor 2016. An enduring shell artefact tradition from Timor-Leste: Oliva bead production from the Pleistocene to Late Holocene at Jerimalai, Lene Hara, and Matja Kuru 1 and 2. PLoS ONE 11(8):e0161071. doi.org/10.1371/journal.pone.0161071.

Lankton, J. and B. Gratuze 2011. Glass samples from Timor and Papua New Guinea: LA-ICP-MS chemical compositional analysis. Unpublished report.

Li, J. 2010. Qing dynasty ceramics. In Li Zhiyan, V.L. Bower and H. Li (eds), Chinese ceramics from the Palaeolithic Period through the Qing Dynasty, pp. 459-533. Yale University Press, New Haven.

Lyman, R.L. 1994. Vertebrate taphonomy. Cambridge University Press, Cambridge.

Macintosh, D. 1977. Chinese Blue and White porcelain. David and Charles, London. 
Marwick, B. 2008. What attributes are important for the measurement of assemblage reduction intensity? Results from an experimental stone artefact assemblage with relevance to the Hoabinhian of Mainland Southeast Asia. Journal of Archaeological Science 35:1189-1200. doi.org/10.1016/j.jas. 2007.08.007.

Marwick, B., C. Clarkson, S. O'Connor and S. Collins 2016. Early modern human technology from Jerimalai, East Timor. Journal of Human Evolution 101:45-64. doi.org/10.1016/j.jhevol.2016.09.004.

McCormac, F.G., A.G. Hogg, P.G. Blackwell, C.E. Buck, T.F.G. Higham and P.J. Reimer 2004. Shcal04 Southern Hemisphere Calibration, 0-11.0 Cal Kyr BP. Radiocarbon 46(3):1087-1092. doi.org/ $10.1017 / \mathrm{s} 0033822200033014$.

McWilliam, A. 2007. Harbouring traditions in East Timor: Marginality in a lowland entrepôt. Modern Asian Studies 41(6):1113-1143. doi.org/10.1017/s0026749x07002843.

McWilliam, A., D. Bulbeck, S. Brockwell and S. O'Connor 2012. The cultural legacy of Makassar stone in East Timor. The Asia Pacific Journal of Anthropology 13(3):262-279. doi.org/10.1080/14442213. 2012.674054 .

O'Connor, S., A. McWilliam, J.N. Fenner and S. Brockwell 2012. Examining the origin of fortifications in East Timor: Social and environmental factors. The Journal of Island and Coastal Archaeology 7(2):200-218. doi.org/10.1080/15564894.2011.619245.

Pannell, S. and S. O'Connor 2005. Toward a cultural topography of cave use in East Timor: A preliminary study. Asian Perspectives 44(1):193-206. doi.org/10.1353/asi.2005.0011.

Phan, H.L., N. Đình Chiến, N. Quang Ngọc 1995. Bat Trang ceramics 14th-19th centuries. Gio Publishers, Hanoi.

Piper, P.J. 2006. A taphonomic assessment of the small vertebrate remains from the cave site of Liang Bua, Flores Eastern Indonesia. Unpublished report for Pusat Arkeologi Nasional Indonesia (ARKENAS).

Piper, P.J. and N. Amano 2011. A report on the animal remains from the 2008 excavations at Macapainara, East Timor. Unpublished report. The Australian National University, Canberra. hdl.handle.net/1885/ 111566. Accessed 17 March 2020.

Rinaldi, M. 1989. Kraak porcelain: A moment in the history of trade. Bamboo Publishing, London.

Rooney, J.R. and J.L. Robertson 1996. Equine pathology. Iowa State University Press, Ames.

Rye, O.S. 1981. Pottery technology: Principles and reconstruction. Taraxacum, Washington D.C.

Satō, M. 1981. Chinese ceramics: A short history. Translated into English and adapted by K. Hanaoka and S. Barberi. John Weatherhill, New York/Tokyo.

Scheans, D.J., K.L. Hutterer and R.L. Cherry 1970. A newly discovered blade tool industry from the central Philippines. Asian Perspectives 13:179-181.

Scheurleer, D.F.L. 1974. Chinese export porcelain: Chine de commande. Faber and Faber, London.

Schmid, E. 1972. Atlas of animal bones. Elsevier, Amsterdam.

Scott, E. and J. Rooney 2001. Non-articular periostosis of a proximal phalanx of Equus conversidens. PaleoBios 21(2):12-14.

Scott, R.E. 1992. Archaism and invention: Sources of ceramic design in the Ming and Qing dynasties. In G. Kuwayam (ed.), New perspectives on the art of ceramics in China, pp. 80-98. Far Eastern Art Council, Los Angeles County Museum of Art, Los Angeles.

Shepard, A.O. 1974. Ceramics for the archaeologist. Carnegie Institution Publications, Washington D.C.

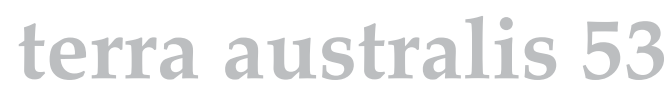


Silver, I.A. 1970. The ageing of domestic animals. In D.R. Brothwell and E.S. Higgs (eds), Science in archaeology: A survey of progress and research, pp. 250-268. Thames and Hudson, London.

Skertchly, S.B.J. 1890. On fire-making in North Borneo. The Journal of the Anthropological Institute of Great Britain and Ireland 19:445-452. doi.org/10.2307/2842488.

Staperd, D. and L. Johansen 1999. Flint and pyrite: Making fire in the stone-age. Antiquity 73:765-777. doi.org/10.1017/s0003598x00065510.

Stiner, M., S.L. Kuhn and E. Gülec 2013. Early Upper Paleolithic shell beads at Üçağizili Cave I (Turkey): Technology and the socioeconomic context of ornament life-histories. Journal of Human Evolution 64:380-398. doi.org/10.1016/j.jhevol.2013.01.008.

Szabó, K. 2010. Shell artefacts and shell-working within the Lapita Cultural Complex. Journal of Pacific Archaeology 1:115-127.

Vanhaeren, M., F. D'errico, K. Van Niekerk, C. Henshilwood and R.M. Erasums 2013. Thinking strings: Additional evidence for personal ornament use in the Middle Stone Age at Blombos Cave, South Africa. Journal of Human Evolution 64:500-517. doi.org/10.1016/j.jhevol.2013.02.001.

Villiers, J. 1981. Trade and society in the Banda Islands in the sixteenth century. Modern Asian Studies 15(4):723-750. doi.org/10.1017/s0026749x0000874x.

von den Driesch, A. 1976. A guide to the measurement of animal bones from archaeological sites. . Bulletin No. 1. Peabody Museum of American Archaeology and Ethnology, Cambridge, Massachusetts.

Young, C.M., M.-F. Dupoizat and E.W. Lane (eds) 1982. Vietnamese ceramics. Southeast Asian Ceramics Society, Singapore.

\section{Appendices}

Table 2.A1. Macapainara tradeware.

\begin{tabular}{|c|c|c|c|c|c|c|}
\hline $\begin{array}{l}\text { Square/ } \\
\text { spit }\end{array}$ & Classification & Date & Form & $\begin{array}{l}\text { Vessel } \\
\text { part }\end{array}$ & Fabric & $\begin{array}{l}\text { Elucidatory comparisons in the ceramics } \\
\text { literature }\end{array}$ \\
\hline$A / 1$ & $\begin{array}{l}\text { Transitional cf. } \\
\text { Jiajing }\end{array}$ & $\begin{array}{l}\text { Mid-17th } \\
\text { century }\end{array}$ & Bowl & $\begin{array}{l}\text { Lower } \\
\text { body }\end{array}$ & $\begin{array}{l}\text { Fine } \\
\text { stoneware }\end{array}$ & $\begin{array}{l}\text { Bowl from the c. } 1643 \text { 'Hatcher recovery' } \\
\text { (Harrisson 1995: Colour Plate 16) }\end{array}$ \\
\hline $\mathrm{A} / 2$ & $\begin{array}{l}\text { Ming/ } \\
\text { Transitional }\end{array}$ & $\begin{array}{l}\text { 16th-17th } \\
\text { centuries }\end{array}$ & Bowl & Body & $\begin{array}{l}\text { Fine } \\
\text { stoneware }\end{array}$ & None (sherd lacks decorations) \\
\hline$A / 2$ & $\begin{array}{l}\text { Singburi } \\
\text { (Thailand) }\end{array}$ & $\begin{array}{l}\text { 16th-17th } \\
\text { centuries }\end{array}$ & $\begin{array}{l}\text { Large } \\
\text { jar }\end{array}$ & Shoulder & Stoneware & $\begin{array}{l}\text { Unglazed variant of Harrisson's (1990) } \\
\text { 'Sawankhalok' jars, actually made mainly } \\
\text { in Singburi, till the early 18th century } \\
\text { (Brown 2004) }\end{array}$ \\
\hline $\mathrm{A} / 2$ & $\begin{array}{l}\text { Zhangzhou } \\
\text { (plainware?) }\end{array}$ & 17th century & $\begin{array}{l}\text { Bowl/ } \\
\text { plate }\end{array}$ & Base & Stoneware & $\begin{array}{l}\text { Swatow plainware/celadon ('3G/VI'), } \\
\text { Bulbeck (1992:560-564, 569) }\end{array}$ \\
\hline$A / 2$ & $\begin{array}{l}\text { Zhangzhou } \\
\text { blue-and-white } \\
\text { 'pseudomorph' }\end{array}$ & $\begin{array}{l}\text { Late 17th } \\
\text { century }\end{array}$ & Bowl & $\begin{array}{l}\text { Lower } \\
\text { body }\end{array}$ & Stoneware & Harrisson (1995: Plate 79) \\
\hline$A / 2$ & $\begin{array}{l}\text { Early Qing } \\
\text { red overglaze } \\
\text { decorated }\end{array}$ & $\begin{array}{l}\text { Late } 17 \text { th - } \\
\text { early } 18 \text { th } \\
\text { century }\end{array}$ & Tile & Border & $\begin{array}{l}\text { Fine } \\
\text { stoneware }\end{array}$ & $\begin{array}{l}\text { Related to the tiles made in China, based } \\
\text { on their Dutch prototype, during the reign } \\
\text { of Emperor Kangxi (Scheurleer 1974:56, 99) }\end{array}$ \\
\hline$A / 2$ & $\begin{array}{l}\text { Early Qing } \\
\text { blue-and-white }\end{array}$ & $\begin{array}{l}\text { Early 18th } \\
\text { century }\end{array}$ & Bowl & Footring & $\begin{array}{l}\text { Fine } \\
\text { stoneware }\end{array}$ & $\begin{array}{l}\text { Batik pattern (Harrisson 1995:79, 80) in } \\
\text { the lavender tone characteristic of early } \\
\text { 18th-century Chinese Blue and White } \\
\text { (Macintosh 1977:77, 83) }\end{array}$ \\
\hline
\end{tabular}




\begin{tabular}{|c|c|c|c|c|c|c|}
\hline $\begin{array}{l}\text { Square/ } \\
\text { spit }\end{array}$ & Classification & Date & Form & $\begin{array}{l}\text { Vessel } \\
\text { part }\end{array}$ & Fabric & $\begin{array}{l}\text { Elucidatory comparisons in the ceramics } \\
\text { literature }\end{array}$ \\
\hline $\begin{array}{l}A / 2, A / 3 \\
\text { (4 sherds) }\end{array}$ & \begin{tabular}{|l} 
Qing \\
(Yongzheng) \\
copper spotted \\
underglaze \\
\end{tabular} & $\begin{array}{l}\text { Early } 18 \text { th } \\
\text { century }\end{array}$ & Jarlet & $\begin{array}{l}\text { Basal } \\
\text { rim, body }\end{array}$ & Porcelain & $\begin{array}{l}\text { Illustrated wares with underglaze red } \\
\text { but no underglaze blue are dated to the } \\
\text { Yongzheng reign, 1723-1735 (Satō 1981: } \\
\text { Fig. 302; Li 2010: Fig. 9.4) }\end{array}$ \\
\hline$A / 3$ & $\begin{array}{l}\text { Vietnam } \\
\text { monochrome }\end{array}$ & $\begin{array}{l}\text { 16th-17th } \\
\text { centuries }\end{array}$ & $\begin{array}{l}\text { Closed } \\
\text { vessel }\end{array}$ & Body & Stoneware & $\begin{array}{l}\text { Frasché (1976: Fig. 108); see also Frasché } \\
\text { (1976:97-99) }\end{array}$ \\
\hline$A / 4$ & $\begin{array}{l}\text { Vietnam } \\
\text { monochrome }\end{array}$ & $\begin{array}{l}\text { 16th-17th } \\
\text { centuries }\end{array}$ & Bowl & Body & Stoneware & Frasché $(1976: 99,137)$ \\
\hline $\mathrm{A} / 4$ & $\begin{array}{l}\text { Transitional } \\
\text { blue-and-white }\end{array}$ & 17th century & Bowl & Body & Porcelain & $\begin{array}{l}\text { May match the late Transitional (Shunhzi) } \\
\text { covered bowl illustrated by Satō (1981: } \\
\text { Fig. 290) }\end{array}$ \\
\hline$A / 5$ & $\begin{array}{l}\text { Transitional/ } \\
\text { Qing blue-and- } \\
\text { white }\end{array}$ & $\begin{array}{l}\text { 17th-18th } \\
\text { centuries }\end{array}$ & $\begin{array}{l}\text { Bowl/ } \\
\text { cup }\end{array}$ & Rim & Porcelain & None (decoration is undiagnostic) \\
\hline$A / 7$ & $\begin{array}{l}\text { Vietnam } \\
\text { monochrome }\end{array}$ & $\begin{array}{l}\text { 15th-17th } \\
\text { centuries }\end{array}$ & $\begin{array}{l}\text { Lime } \\
\text { pot }\end{array}$ & $\begin{array}{l}\text { Handle } \\
\text { fragment }\end{array}$ & Stoneware & $\begin{array}{l}\text { Young et al. (1982: Plates 182, 183); Phan } \\
\text { et al. (1995: Plate 61) }\end{array}$ \\
\hline$A / 7$ & $\begin{array}{l}\text { Ming blue-and- } \\
\text { white }\end{array}$ & 16th century & $\begin{array}{l}\text { Bowl/ } \\
\text { plate }\end{array}$ & $\begin{array}{l}\text { Base } \\
\text { abutting } \\
\text { footring }\end{array}$ & Stoneware & $\begin{array}{l}\text { Clear, strong blue coloration and } \\
\text { greenish tinged glaze suggest late Ming } \\
\text { (cf. Macintosh 1977) }\end{array}$ \\
\hline$A / 7$ & $\begin{array}{l}\text { Singburi } \\
\text { (Thailand) }\end{array}$ & $\begin{array}{l}\text { 16th-17th } \\
\text { centuries }\end{array}$ & $\begin{array}{l}\text { Large } \\
\text { jar }\end{array}$ & Body & Stoneware & $\begin{array}{l}\text { Black glazed variant of Harrisson's (1990) } \\
\text { 'Sawankhalok' jars, actually made mainly } \\
\text { in Singburi, till the early 18th century } \\
\text { (Brown 2004) }\end{array}$ \\
\hline$A / 7$ & Qing celadon & $\begin{array}{l}\text { Late } 17 \text { th - } \\
\text { early } 18 \text { th } \\
\text { century }\end{array}$ & Jаг & Cover rim & Stoneware & $\begin{array}{l}\text { Most plausible parallel are early Qing } \\
\text { vessels made in imitation of 13th-14th- } \\
\text { century celadons but covered with a pale } \\
\text { celadon glaze (see Scott 1992) }\end{array}$ \\
\hline$A / 7$ & $\begin{array}{l}\text { Qing } \\
\text { whiteware }\end{array}$ & $\begin{array}{l}17 \text { th - } \\
\text { early } 18 \text { th } \\
\text { centuries }\end{array}$ & $\begin{array}{l}\text { Closed } \\
\text { vessel }\end{array}$ & Shoulder & Porcelain & $\begin{array}{l}\text { Features consistent with 17th- to early } \\
\text { 18th-century whiteware (cf. Bulbeck 1992: } \\
\text { Tables B-29, B-31) }\end{array}$ \\
\hline$A / 7$ & $\begin{array}{l}\text { European } \\
\text { painted blue- } \\
\text { and-white }\end{array}$ & $\begin{array}{l}\text { Mid-18th } \\
\text { century }\end{array}$ & $\begin{array}{l}\text { Tallish } \\
\text { vessel }\end{array}$ & Body & $\begin{array}{l}\text { Low-fired } \\
\text { stoneware }\end{array}$ & $\begin{array}{l}\text { Mid-18th-century Worcester blue-and-white } \\
\text { 'porcelain' (cf. Branyan et al. 1989:44, 75, } \\
\text { 79, 93, 148, 201, 206) }\end{array}$ \\
\hline $\mathrm{A} / 7(7)$ & $\begin{array}{l}\text { Qing } \\
\text { monochrome }\end{array}$ & $\begin{array}{l}\text { 18th-19th } \\
\text { centuries }\end{array}$ & Jarlet & $\begin{array}{l}\text { Body/ } \\
\text { cover } \\
\text { facet }\end{array}$ & $\begin{array}{l}\text { Semi- } \\
\text { porcelain }\end{array}$ & $\begin{array}{l}\text { Pink semi-porcelain body, as found among } \\
\text { Chinese Qing monochromes (Bulbeck 1992: } \\
\text { 551) }\end{array}$ \\
\hline $\mathrm{A} / 9(1)$ & $\begin{array}{l}\text { Coarse Brown } \\
\text { (Thailand/ } \\
\text { Cambodia) } \\
\end{array}$ & $\begin{array}{l}\text { 16th-17th } \\
\text { centuries }\end{array}$ & Јаг & Shoulder & Stoneware & Harrisson (1990: Plates 149, 150) \\
\hline$A / 9(2)$ & $\begin{array}{l}\text { Coarse Red } \\
\text { (Vietnam) }\end{array}$ & $\begin{array}{l}\text { 17th-18th } \\
\text { centuries }\end{array}$ & Jаг & Body & Stoneware & Harrisson (1990: 39, Plates 106-114) \\
\hline $\begin{array}{l}\text { A/10 } \\
\text { (3 sherds) }\end{array}$ & $\begin{array}{l}\text { Ming } \\
\text { Zhangzhou } \\
\text { blue-and-white }\end{array}$ & 16th century & Dish & $\begin{array}{l}\text { Lower } \\
\text { body }\end{array}$ & Stoneware & Harrisson (1995: Plate 43) \\
\hline $\mathrm{A} / 10$ & $\begin{array}{l}\text { Brittle (South } \\
\text { China/ } \\
\text { Vietnam) } \\
\end{array}$ & 16th century & Jаг & Body & Stoneware & Harrisson (1990) \\
\hline$A / 10$ & $\begin{array}{l}\text { Late Ming blue- } \\
\text { and-white }\end{array}$ & $\begin{array}{l}\text { Late } 16 \text { th - } \\
\text { early } 17 \text { th } \\
\text { century }\end{array}$ & Plate & Footring & Porcelain & $\begin{array}{l}\text { Features consistent with Wanli wares } \\
\text { (Scheurleer 1974:49) }\end{array}$ \\
\hline$A / 11$ & $\begin{array}{l}\text { Ming green } \\
\text { overglaze }\end{array}$ & $\begin{array}{l}\text { Early 16th } \\
\text { century }\end{array}$ & Jarlet & Shoulder & Porcelain & $\begin{array}{l}\text { Hongzhi porcelain bowl (Satō 1981: } \\
\text { Fig. 250) }\end{array}$ \\
\hline
\end{tabular}




\begin{tabular}{|c|c|c|c|c|c|c|}
\hline $\begin{array}{l}\text { Square/ } \\
\text { spit }\end{array}$ & Classification & Date & Form & $\begin{array}{l}\text { Vessel } \\
\text { part }\end{array}$ & Fabric & $\begin{array}{l}\text { Elucidatory comparisons in the ceramics } \\
\text { literature }\end{array}$ \\
\hline$c / 2$ & $\begin{array}{l}\text { Qing } \\
\text { Zhangzhou } \\
\text { blue-and-white }\end{array}$ & $\begin{array}{l}\text { Late } 17 \text { th - } \\
\text { early } 18 \text { th } \\
\text { century }\end{array}$ & Jar & Body & Stoneware & Qing Swatow ('2C/II'), Bulbeck (1992:564) \\
\hline $\begin{array}{l}\text { C/2 } \\
\text { (4 sherds) }\end{array}$ & $\begin{array}{l}\text { Qing } \\
\text { whiteware }\end{array}$ & 18th century & Bowl & Rim & $\begin{array}{l}\text { Semi- } \\
\text { porcelain }\end{array}$ & $\begin{array}{l}\text { Features consistent with 18th-century } \\
\text { whitewares (cf. Bulbeck 1992:577, Tables } \\
\text { B-18, B-31) }\end{array}$ \\
\hline$c / 2$ & $\begin{array}{l}\text { Qing blue-and- } \\
\text { white }\end{array}$ & $\begin{array}{l}\text { Late 18th } \\
\text { century }\end{array}$ & $\begin{array}{l}\text { Closed } \\
\text { vessel }\end{array}$ & Body & $\begin{array}{l}\text { Fine } \\
\text { stoneware }\end{array}$ & Qianlong flask (SatĐ 1981: Fig. 300) \\
\hline$c / 4$ & $\begin{array}{l}\text { Early Qing } \\
\text { blackware }\end{array}$ & $\begin{array}{l}\text { Early 18th } \\
\text { century }\end{array}$ & $\begin{array}{l}\text { Closed } \\
\text { vessel }\end{array}$ & Body & Stoneware & $\begin{array}{l}\text { Closest match found is the 'iron rust' } \\
\text { blackwares of the early 18th-century } \\
\text { Yongzheng reign (Li 2010:489) }\end{array}$ \\
\hline $\mathrm{c} / 8$ & $\begin{array}{l}\text { Zhangzhou } \\
\text { plain }\end{array}$ & 17th century & $\begin{array}{l}\text { Open } \\
\text { vessel }\end{array}$ & Base & $\begin{array}{l}\text { Fine } \\
\text { stoneware }\end{array}$ & $\begin{array}{l}\text { Swatow plainware ('4G/VI'), Bulbeck } \\
(1992: 564)\end{array}$ \\
\hline$C / 9$ & $\begin{array}{l}\text { Ming blue-and- } \\
\text { white }\end{array}$ & 16th century & Plate & Rim & $\begin{array}{l}\text { Fine } \\
\text { stoneware }\end{array}$ & Guy (1986: Fig. 71) \\
\hline$c / 9$ & $\begin{array}{l}\text { Ming/ } \\
\text { Transitional } \\
\text { blue-and-white }\end{array}$ & $\begin{array}{l}\text { 16th-17th } \\
\text { centuries }\end{array}$ & Bowl & Rim & Porcelain & $\begin{array}{l}\text { Unwavering, thick blue line slightly below } \\
\text { rim tip is found with many 16th- and 17th- } \\
\text { century bowls and dishes (see Guy 1986; } \\
\text { Harrisson 1995) }\end{array}$ \\
\hline$c / 10$ & $\begin{array}{l}\text { Guangdong } \\
\text { blackware }\end{array}$ & $\begin{array}{l}\text { Mid-2nd } \\
\text { millennium }\end{array}$ & Jаг & Body & Stoneware & $\begin{array}{l}\text { Guangdong jar with Temmoku-like glaze } \\
\text { (Harrisson 1990) }\end{array}$ \\
\hline$c / 10$ & $\begin{array}{l}\text { Ming } \\
\text { Zhangzhou } \\
\text { blue-and-white }\end{array}$ & 16th century & $\begin{array}{l}\text { Open } \\
\text { vessel }\end{array}$ & Base & $\begin{array}{l}\text { Fine } \\
\text { stoneware }\end{array}$ & Ming Swatow ('4D/VI'), Bulbeck (1992: 564) \\
\hline$c / 10$ & $\begin{array}{l}\text { Zhangzhou } \\
\text { plain }\end{array}$ & 17th century & Plate & Base & $\begin{array}{l}\text { Fine } \\
\text { stoneware }\end{array}$ & $\begin{array}{l}\text { Swatow plainware ('4C/VI'), Bulbeck } \\
\text { (1992: 564) }\end{array}$ \\
\hline$C / 10$ & $\begin{array}{l}\text { Zhangzhou } \\
\text { celadon }\end{array}$ & 17th century & $\begin{array}{l}\text { Bowl/ } \\
\text { plate }\end{array}$ & Body & $\begin{array}{l}\text { Fine } \\
\text { stoneware }\end{array}$ & $\begin{array}{l}\text { Swatow plainware/celadon ('4G/VI'), } \\
\text { Bulbeck (1992:560-64, 569) }\end{array}$ \\
\hline $\begin{array}{l}\text { C/11 } \\
\text { (2 sherds) }\end{array}$ & \begin{tabular}{|l|} 
(Ming) \\
Zhangzhou \\
(plainware?) \\
\end{tabular} & $\begin{array}{l}\text { 16th-17th } \\
\text { centuries }\end{array}$ & $\begin{array}{l}\text { Bowl/ } \\
\text { plate }\end{array}$ & Body & $\begin{array}{l}\text { Fine } \\
\text { stoneware }\end{array}$ & $\begin{array}{l}\text { Swatow '5C/VI', Ming Swatow or Swatow } \\
\text { (cf. Bulbeck 1992:564) }\end{array}$ \\
\hline$c / 13$ & $\begin{array}{l}\text { Guangdong } \\
\text { blackware }\end{array}$ & $\begin{array}{l}\text { Mid-late 2nd } \\
\text { millennium }\end{array}$ & Jar & Body & Stoneware & $\begin{array}{l}\text { Guangdong jar with Temmoku-like glaze } \\
\text { (Harrisson 1990) }\end{array}$ \\
\hline $\mathrm{D} / 1$ & $\begin{array}{l}\text { European } \\
\text { printed blue- } \\
\text { and-white }\end{array}$ & $\begin{array}{l}\text { Early 19th } \\
\text { century }\end{array}$ & Plate & Base & Stoneware & $\begin{array}{l}\text { Godden (1974: Fig. 305), 'an underglaze- } \\
\text { blue printed adaptation of Chinese export- } \\
\text { market porcelain' }\end{array}$ \\
\hline $\mathrm{D} / 2$ & $\begin{array}{l}\text { Early Qing } \\
\text { blue-and-white }\end{array}$ & $\begin{array}{l}\text { Early 18th } \\
\text { century }\end{array}$ & $\begin{array}{l}\text { Bowl/ } \\
\text { plate }\end{array}$ & Base & $\begin{array}{l}\text { Semi- } \\
\text { porcelain }\end{array}$ & $\begin{array}{l}\text { Batik pattern (Harrisson 1995:79, 80) } \\
\text { in early 18th-century lavender tone } \\
\text { (Macintosh 1977:77, 83) }\end{array}$ \\
\hline $\mathrm{D} / 2$ & $\begin{array}{l}\text { European } \\
\text { creamware }\end{array}$ & $\begin{array}{l}\text { Late 18th } \\
\text { century }\end{array}$ & $\begin{array}{l}\text { Teapot/ } \\
\text { tureen }\end{array}$ & Cover & $\begin{array}{l}\text { Fine } \\
\text { stoneware }\end{array}$ & $\begin{array}{l}\text { Creamware teapots and tureens are } \\
\text { characteristic of late 18th-century British } \\
\text { pottery (Godden 1974) }\end{array}$ \\
\hline $\mathrm{D} / 2$ & $\begin{array}{l}\text { Vietnam blue- } \\
\text { and-white }\end{array}$ & 19th century & Tea tray & Base & Stoneware & Phan et al. (1995: Plate 209) \\
\hline $\mathrm{D} / 4$ & $\begin{array}{l}\text { Ming blue-and- } \\
\text { white }\end{array}$ & $\begin{array}{l}\text { Late 16th } \\
\text { century }\end{array}$ & Plate & Rim & $\begin{array}{l}\text { Fine } \\
\text { stoneware }\end{array}$ & Harrisson (1995: Plate 2) \\
\hline $\mathrm{D} / 4$ & $\begin{array}{l}\text { Guangdong } \\
\text { brownware }\end{array}$ & $\begin{array}{l}\text { Mid-late 2nd } \\
\text { millennium }\end{array}$ & Jar & Shoulder & Stoneware & Guangdong jar (Harrisson 1990) \\
\hline$D / 4$ & $\begin{array}{l}\text { Vietnam } \\
\text { brownware }\end{array}$ & 18th century & Vase & Shoulder & Stoneware & Phan et al. (1995: Plate 149) \\
\hline$D / 5$ & $\begin{array}{l}\text { Vietnam ivory } \\
\text { ware }\end{array}$ & $\begin{array}{l}\text { 17th-19th } \\
\text { centuries }\end{array}$ & Vase & Body & $\begin{array}{l}\text { Semi- } \\
\text { porcelain }\end{array}$ & Phan et al. (1995: Plates 96, 157, 194) \\
\hline
\end{tabular}




\begin{tabular}{|c|c|c|c|c|c|c|}
\hline $\begin{array}{l}\text { Square/ } \\
\text { spit }\end{array}$ & Classification & Date & Form & $\begin{array}{l}\text { Vessel } \\
\text { part }\end{array}$ & Fabric & $\begin{array}{l}\text { Elucidatory comparisons in the ceramics } \\
\text { literature }\end{array}$ \\
\hline $\mathrm{D} / 5$ & $\begin{array}{l}\text { Qing blue-and- } \\
\text { white }\end{array}$ & $\begin{array}{l}\text { Late 18th } \\
\text { century }\end{array}$ & Bowl & Cavetto & Porcelain & $\begin{array}{l}\text { Orange-peel effect to dead white glaze, } \\
\text { and dark grey decorations, typically } \\
\text { late 18th century (Scheurleer 1974:32; } \\
\text { Macintosh 1977:83) }\end{array}$ \\
\hline $\mathrm{D} / 5$ & $\begin{array}{l}\text { Qing } \\
\text { monochrome }\end{array}$ & 19th century & Bowl & Cavetto & Stoneware & $\begin{array}{l}\text { Moulded 'utility' ware (cf. Harrisson } \\
\text { 1995:101-102) }\end{array}$ \\
\hline $\mathrm{D} / 7$ & $\begin{array}{l}\text { Vietnam } \\
\text { monochrome }\end{array}$ & $\begin{array}{l}\text { 16th-17th } \\
\text { centuries }\end{array}$ & $\begin{array}{l}\text { Lime } \\
\text { pot }\end{array}$ & $\begin{array}{l}\text { Handle } \\
\text { fragment }\end{array}$ & $\begin{array}{l}\text { Low-fired } \\
\text { stoneware }\end{array}$ & Phan et al. (1995: Plate 61) \\
\hline $\mathrm{D} / 7$ & $\begin{array}{l}\text { Late Ming blue- } \\
\text { and-white }\end{array}$ & $\begin{array}{l}\text { Late } 16 \text { th - } \\
\text { early } 17 \text { th } \\
\text { century }\end{array}$ & Jar & Body & Porcelain & $\begin{array}{l}\text { Finely graded washes of blue typical of } \\
\text { Wanli wares (Macintosh 1977:6), especially } \\
\text { c. } 1600 \text { jar illustrated by Harrisson } \\
\text { (1995: Plate 7) }\end{array}$ \\
\hline $\mathrm{D} / 8$ & $\begin{array}{l}\text { Kraaksporselein } \\
\text { blue-and-white }\end{array}$ & $\begin{array}{l}\text { Late } 16 \text { th - } \\
\text { early } 17 \text { th } \\
\text { century }\end{array}$ & Plate & Footring & Stoneware & Rinaldi (1989: Plates 70, 89) \\
\hline $\mathrm{D} / 8$ & $\begin{array}{l}\text { Kraaksporselein } \\
\text { blue-and-white }\end{array}$ & $\begin{array}{l}\text { Late } 16 \text { th - } \\
\text { early } 17 \text { th } \\
\text { century }\end{array}$ & Plate & Rim & Porcelain & Rinaldi (1989: Plates 85-86, 90) \\
\hline $\begin{array}{l}\text { D/9 } \\
\text { (3 sherds) }\end{array}$ & $\begin{array}{l}\text { Guangdong } \\
\text { blackware }\end{array}$ & 19th century & Jаг & Body & Stoneware & $\begin{array}{l}\text { Imitation gusi Guangdong jars (cf. Harrisson } \\
\text { 1990:53, Plate 156) }\end{array}$ \\
\hline $\mathrm{D} / 10$ & $\begin{array}{l}\text { Coarse Brown } \\
\text { (Thailand/ } \\
\text { Cambodia) } \\
\end{array}$ & $\begin{array}{l}\text { 16th-17th } \\
\text { centuries }\end{array}$ & Jar & Body & Stoneware & Harrisson (1990) \\
\hline$D / 11$ & $\begin{array}{l}\text { Ming } \\
\text { Zhangzhou } \\
\text { blue-and-white }\end{array}$ & 16th century & Dish & Base & Stoneware & $\begin{array}{l}\text { Ming Swatow }\left({ }^{\prime} 5 D / I^{\prime}\right) \text {, Bulbeck } \\
(1992: 564)\end{array}$ \\
\hline
\end{tabular}

Sources: See references throughout table.

Table 2.A2. Macapainara representative shellfish data (Square D, NISP and MNI).

\begin{tabular}{|l|r|r|r|r|r|r|r|r|r|r|r|r|r|r|r|r|r|}
\hline Taxon & $\mathbf{1}$ & $\mathbf{2}$ & $\mathbf{3}$ & $\mathbf{4}$ & $\mathbf{5}$ & $\mathbf{6}$ & $\mathbf{7}$ & $\mathbf{8}$ & $\mathbf{9}$ & $\mathbf{1 0}$ & $\mathbf{1 1}$ & $\mathbf{1 2}$ & $\mathbf{1 3}$ & $\mathbf{1 4}$ & $\mathbf{1 5}$ & $\mathbf{1 6}$ & Total \\
\hline Chiton sp. & $<1$ & $<$ & 1 & 3 & 1 & 1 & 1 & 1 & $<$ & 1 & 3 & - & 2 & 1 & - & - & 15 \\
\hline Patella sp. & - & - & 6 & 3 & 9 & 8 & 6 & 1 & - & 1 & - & 3 & 4 & - & - & - & 41 \\
\hline Haliotis crebrisculpta & - & - & - & - & - & - & - & - & 2 & - & 1 & 1 & - & 1 & - & - & 5 \\
\hline Haliotis varia & - & 4 & 1 & 10 & 8 & 16 & 14 & - & - & - & - & - & - & - & - & - & 53 \\
\hline Haliotis sp. & $<$ & - & - & 5 & - & 5 & - & 2 & 2 & 2 & 2 & $<1$ & 3 & $<1$ & - & - & 21 \\
\hline Trochus maculatus & 1 & 2 & 7 & 17 & 1 & 49 & 8 & 11 & 5 & 6 & 16 & 4 & 4 & 7 & $<1$ & $<1$ & 138 \\
\hline Trochus sp. & - & 6 & $<1$ & 2 & - & $<1$ & - & $<1$ & 3 & 4 & 5 & $<1$ & $<1$ & 6 & $<1$ & $<1$ & 26 \\
\hline Tectus fenestratus & - & 6 & 3 & 11 & - & 44 & 13 & 5 & - & 5 & 43 & 26 & 28 & 48 & 6 & 3 & 241 \\
\hline Rochia nilotica & 1 & 8 & 8 & 10 & $<1$ & 9 & 5 & 5 & 2 & 2 & 14 & 15 & 7 & 4 & 1 & $<1$ & 91 \\
\hline Monodonta labio & - & - & - & 1 & - & $<1$ & - & - & - & - & - & - & - & - & - & - & 1 \\
\hline Turbo argyrostomus & - & - & - & - & - & - & - & 1 & - & - & - & - & - & - & - & - & 1 \\
\hline Turbo bruneus & - & 11 & 18 & 22 & 58 & 82 & 35 & 52 & 6 & 11 & 35 & 29 & 12 & 15 & 2 & - & 395 \\
\hline Turbo chrysostomus & - & 14 & 4 & 3 & 21 & 28 & 8 & 11 & 2 & - & 5 & 9 & 6 & 7 & 1 & - & 119 \\
\hline Turbo reevei & - & - & - & - & - & - & - & 1 & - & - & - & - & - & - & - & - & 1 \\
\hline Turbo sp. & - & - & 4 & $<1$ & 4 & 5 & - & 1 & 2 & 8 & 14 & 5 & $<1$ & 4 & $<1$ & 1 & 48 \\
\hline Turbo spp. opercula & 21 & 27 & 14 & 53 & 3 & 66 & 51 & 27 & 13 & 10 & 15 & 7 & 15 & 19 & 2 & 1 & 344 \\
\hline Lunella cinerea & - & - & - & - & 1 & - & - & 1 & - & - & 1 & - & 1 & - & - & - & 4 \\
\hline Bellastraea squamifera & - & 5 & 1 & 2 & - & $<1$ & 4 & - & - & - & 1 & 6 & 2 & 1 & 1 & - & 23 \\
\hline Angaria delphinus & 1 & 6 & 5 & 6 & - & 27 & 8 & 9 & - & 4 & 3 & 5 & 4 & 8 & 1 & 1 & 88 \\
\hline Nerita albicilla & - & $<1$ & 4 & 6 & - & 28 & 15 & 6 & 3 & 1 & 6 & 1 & 3 & 2 & 2 & - & 77 \\
\hline
\end{tabular}




\begin{tabular}{|c|c|c|c|c|c|c|c|c|c|c|c|c|c|c|c|c|c|}
\hline Taxon & 1 & 2 & 3 & 4 & 5 & 6 & 7 & 8 & 9 & 10 & 11 & 12 & 13 & 14 & 15 & 16 & Total \\
\hline Nerita exuvia & - & - & - & $<1$ & - & 5 & 1 & 2 & 1 & 2 & 1 & - & - & - & - & - & 12 \\
\hline Nerita plicata & 1 & 1 & 2 & 9 & - & 25 & 7 & 7 & 2 & - & - & - & - & 1 & - & - & 55 \\
\hline Nerita polita & - & 1 & 1 & 2 & $<1$ & 6 & 7 & - & 1 & 4 & 2 & 1 & 6 & 4 & 1 & - & 36 \\
\hline Nerita undata & - & - & - & - & - & 2 & 8 & 7 & 1 & - & - & - & 4 & - & - & - & 22 \\
\hline Nerita sp. & - & - & $<1$ & - & 1 & $<1$ & - & 2 & $<1$ & $<1$ & $<1$ & 2 & 6 & $<1$ & $<1$ & - & 11 \\
\hline Nerita spp. opercula & - & - & - & - & - & - & 1 & - & - & - & - & - & - & - & - & - & 1 \\
\hline Cerithium nodulosum & - & - & - & - & - & 2 & 1 & - & - & - & - & 1 & - & - & - & - & 4 \\
\hline Melanoides tuberculata & - & - & - & - & - & - & - & - & - & 1 & - & - & - & - & - & - & 1 \\
\hline Conomurex luhuanus & - & - & - & 1 & 5 & 6 & 2 & 4 & - & - & - & - & - & 4 & 1 & - & 23 \\
\hline Lentigo lentiginosus & - & - & - & 1 & - & - & - & - & - & - & 2 & - & 2 & - & - & - & 5 \\
\hline Canarium labiatum & - & - & - & - & - & - & - & - & - & - & - & - & - & 1 & - & - & 1 \\
\hline Lambis sp. & $<1$ & 1 & 2 & 2 & 2 & 3 & $<1$ & 1 & 1 & 2 & 2 & 1 & 1 & 1 & 1 & $<1$ & 20 \\
\hline Naticidae sp. & - & 1 & - & - & - & - & - & - & - & - & - & - & - & - & - & - & 1 \\
\hline Сургаеа tigris & - & - & 1 & $<1$ & - & 1 & 6 & 5 & $<1$ & 1 & $<1$ & 2 & $<1$ & - & 1 & - & 17 \\
\hline Сургаеа sp. & $<1$ & 4 & 1 & 3 & 3 & 1 & $<1$ & $<1$ & 2 & 1 & 3 & 1 & 1 & $<1$ & - & $<1$ & 20 \\
\hline Lyncina vitellus & - & - & 2 & 5 & - & 8 & 4 & 3 & 2 & 3 & 1 & 1 & 3 & 2 & $<1$ & $<1$ & 34 \\
\hline Drupa sp. & - & - & - & - & 1 & - & - & - & - & - & - & - & - & - & - & - & 1 \\
\hline Thais aculeata & - & - & - & - & - & - & - & 1 & - & - & - & - & - & - & - & - & 1 \\
\hline Mancinella armigera & - & - & - & - & - & 3 & - & 1 & - & - & - & - & - & - & - & - & 4 \\
\hline Menathais tuberosa & - & - & - & - & - & - & - & - & 1 & 1 & - & - & - & - & - & - & 2 \\
\hline Thais sp. & - & - & - & - & - & - & - & $<1$ & - & - & - & - & - & - & - & - & - \\
\hline Muricidae sp. & - & - & - & - & - & - & - & 1 & - & - & 3 & - & - & - & - & - & 4 \\
\hline Mipus erosus & - & - & - & - & - & - & - & - & - & - & - & - & - & 1 & - & - & 1 \\
\hline Pollia fumosa & - & $<1$ & - & $<1$ & - & 1 & $<1$ & $<1$ & - & - & - & - & 1 & - & $<1$ & - & 2 \\
\hline Pollia sp. & - & - & - & - & 1 & - & - & - & - & - & - & 1 & - & 1 & - & - & 3 \\
\hline Nassarius arcularia & - & 2 & 2 & 8 & 14 & 16 & 13 & 8 & 3 & - & - & 1 & 6 & 6 & - & - & 79 \\
\hline Nassarius pauper & - & - & - & - & - & - & - & - & - & 1 & - & - & - & - & - & - & 1 \\
\hline Nassariidae sp. & - & - & - & - & - & - & 1 & - & - & - & - & - & - & - & - & - & 1 \\
\hline $\begin{array}{l}\text { Latirolagena } \\
\text { smaragdulus }\end{array}$ & - & - & - & - & - & 2 & - & - & 1 & - & $<1$ & 1 & 2 & 2 & - & - & 8 \\
\hline Latirus sp. & - & - & - & - & - & - & - & - & - & - & - & - & - & 1 & - & - & 1 \\
\hline Vasum ceramicum & - & 1 & - & - & - & - & - & - & - & - & - & - & - & - & - & - & 1 \\
\hline Vasum turbinellus & - & - & - & 2 & - & 11 & 3 & 4 & - & - & 3 & 1 & $<1$ & 1 & - & - & 25 \\
\hline Vasum sp. & - & - & - & - & - & - & $<1$ & - & - & 1 & - & - & - & - & - & - & 1 \\
\hline Nebularia coffea & - & - & - & - & 1 & - & - & 1 & - & - & - & - & - & - & - & - & 2 \\
\hline Olividae sp. & - & - & - & 1 & - & 1 & - & 2 & - & - & - & - & $<1$ & - & - & - & 4 \\
\hline Hагра sp. & - & - & - & - & - & - & - & - & - & - & - & - & $<1$ & - & - & - & - \\
\hline Cymbiola vespertilio & - & 3 & 3 & 5 & 1 & 4 & 2 & 3 & 1 & 3 & 1 & 2 & 1 & 1 & - & - & 30 \\
\hline Conus canonicus & - & - & - & - & - & 1 & - & - & - & - & - & - & - & - & - & - & 1 \\
\hline Conus litteratus & - & - & 2 & 2 & - & 6 & 1 & 4 & $<1$ & 4 & 1 & 1 & $<1$ & 2 & 1 & - & 24 \\
\hline Conus marmoreus & - & - & 1 & - & - & 5 & $<1$ & 1 & 1 & $<1$ & $<1$ & - & 1 & $<1$ & - & - & 9 \\
\hline Conus omaria & - & - & 1 & - & - & - & - & - & - & - & - & - & - & - & - & - & 1 \\
\hline Conus pennaceus & - & - & - & - & - & 1 & - & - & - & - & $<1$ & - & - & - & - & - & 1 \\
\hline Conus striatus & - & - & - & 2 & - & $<1$ & $<1$ & - & $<1$ & - & $<1$ & - & $<1$ & $<1$ & $<1$ & - & 2 \\
\hline Conus sp. & 1 & 1 & 3 & 2 & 1 & 5 & 2 & 1 & $<1$ & - & $<1$ & - & 1 & $<1$ & $<1$ & $<1$ & 17 \\
\hline Terebra felina & - & - & - & - & - & - & $<1$ & - & - & - & - & - & - & - & - & - & - \\
\hline Bullidae sp. & - & - & - & - & - & 2 & 2 & $<1$ & - & - & - & 1 & $<1$ & 1 & - & - & 6 \\
\hline Hiррориs hipрориs & - & 2 & - & 1 & 1 & 1 & 1 & 2 & 1 & - & $<1$ & $<1$ & 1 & - & - & $<1$ & 10 \\
\hline
\end{tabular}




\begin{tabular}{|l|r|r|r|r|r|r|r|r|r|r|r|r|r|r|r|r|r|}
\hline Taxon & $\mathbf{1}$ & $\mathbf{2}$ & $\mathbf{3}$ & $\mathbf{4}$ & $\mathbf{5}$ & $\mathbf{6}$ & $\mathbf{7}$ & $\mathbf{8}$ & $\mathbf{9}$ & $\mathbf{1 0}$ & $\mathbf{1 1}$ & $\mathbf{1 2}$ & $\mathbf{1 3}$ & $\mathbf{1 4}$ & $\mathbf{1 5}$ & $\mathbf{1 6}$ & Total \\
\hline Tridacna crocea & 1 & 3 & 1 & 2 & 1 & 3 & 3 & - & - & $<1$ & $<1$ & $<1$ & 1 & $<1$ & $<1$ & $<1$ & 15 \\
\hline Tridacna sp. & - & - & 1 & $<$ & - & - & - & - & - & - & - & - & - & - & - & - & 1 \\
\hline Periglypta puerpera & - & - & - & - & - & - & - & 1 & - & - & - & - & - & - & - & - & 1 \\
\hline Veneridae sp. & - & - & - & - & - & - & - & - & - & - & - & 1 & - & - & - & - & 1 \\
\hline Bivalvia sp. & - & - & - & - & 1 & 1 & 1 & $<1$ & - & - & - & - & $<1$ & $<1$ & - & - & 3 \\
\hline Nautilus sp. & 1 & - & $<1$ & - & $<1$ & 1 & $<1$ & $<1$ & - & - & $<1$ & $<1$ & $<1$ & - & - & - & 2 \\
\hline Total MNI & $\mathbf{3 5}$ & $\mathbf{1 0 9}$ & $\mathbf{9 9}$ & $\mathbf{2 0 2}$ & $\mathbf{1 3 9}$ & $\mathbf{4 9 1}$ & $\mathbf{2 3 4}$ & $\mathbf{1 9 5}$ & $\mathbf{5 8}$ & $\mathbf{7 9}$ & $\mathbf{1 8 3}$ & $\mathbf{1 2 9}$ & $\mathbf{1 2 8}$ & $\mathbf{1 5 2}$ & $\mathbf{2 1}$ & $\mathbf{6}$ & $\mathbf{2 2 6 0}$ \\
\hline
\end{tabular}

Source: Authors' summary. 
This text is taken from Forts and Fortification in Wallacea: Archaeological and Ethnohistoric Investigations, edited by Sue O'Connor, Andrew McWilliam and Sally Brockwell, published 2020 by ANU Press, The Australian National University, Canberra, Australia.

doi.org/10.22459/TA53.2020.02 